\title{
LEVEL II SCOUR ANALYSIS FOR BRIDGE 24 (BERLTH00600024) on TOWN HIGHWAY 60, crossing COX BROOK, BERLIN, VERMONT
}

Open-File Report 98-057

Prepared in cooperation with

VERMONT AGENCY OF TRANSPORTATION

and

FEDERAL HIGHWAY ADMINISTRATION

U.S. Department of the Interior

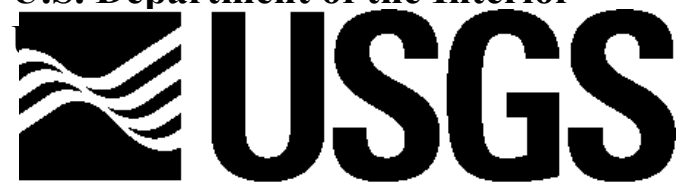

science for a changing world 


\section{LEVEL II SCOUR ANALYSIS FOR BRIDGE 24 (BERLTH00600024) on TOWN HIGHWAY 60, crossing COX BROOK, BERLIN, VERMONT \\ By JAMES R. DEGNAN}

U.S. Geological Survey Open-File Report 98-057

Prepared in cooperation with

VERMONT AGENCY OF TRANSPORTATION

and

FEDERAL HIGHWAY ADMINISTRATION 


\title{
U.S. DEPARTMENT OF THE INTERIOR BRUCE BABBITT, Secretary
}

\author{
U.S. GEOLOGICAL SURVEY
}

Thomas J. Casadevall, Acting Director

For additional information write to:

District Chief

U.S. Geological Survey 361 Commerce Way

Pembroke, NH 03275-3718
Copies of this report may be purchased from:

U.S. Geological Survey

Branch of Information Services

Open-File Reports Unit

Box 25286

Denver, CO 80225-0286 


\section{CONTENTS}

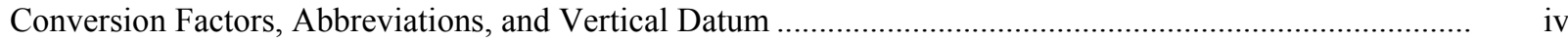

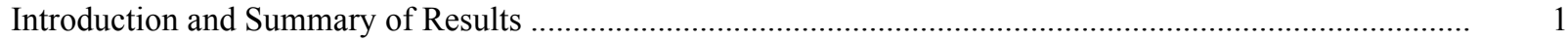

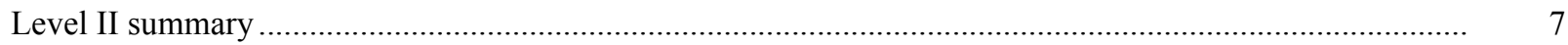

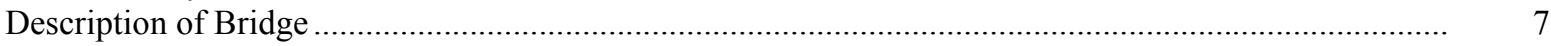

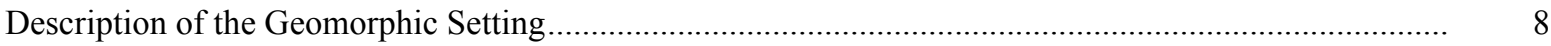

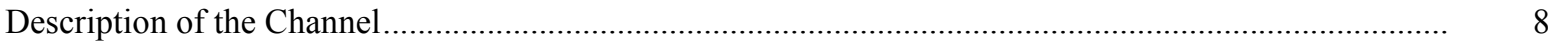

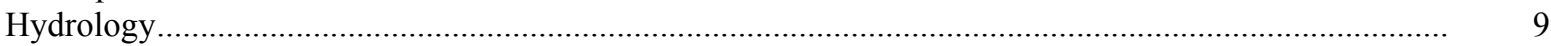

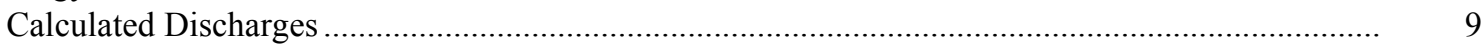

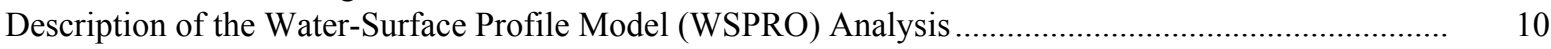

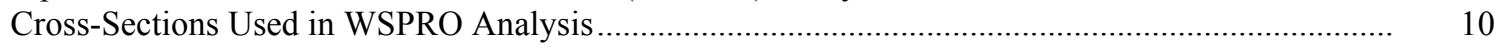

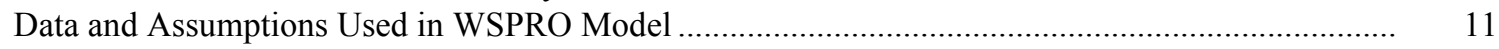

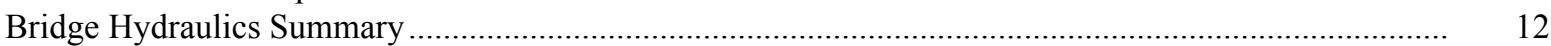

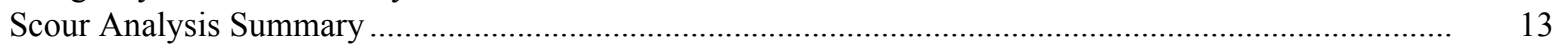

Special Conditions or Assumptions Made in Scour Analysis ..................................................... 13

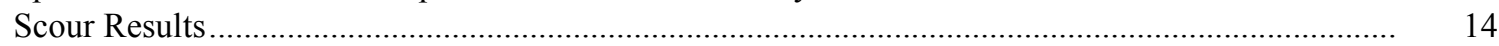

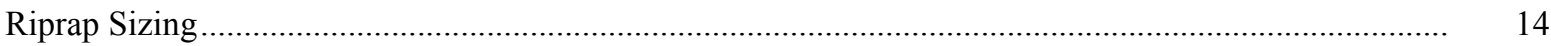

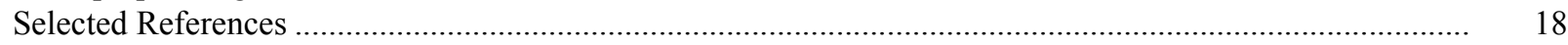

Appendices:

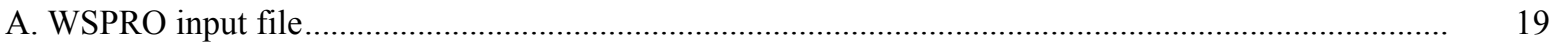

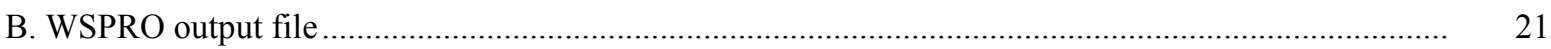

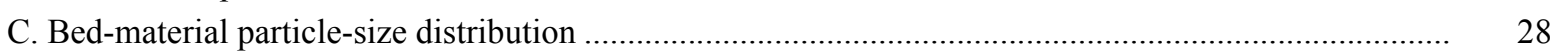

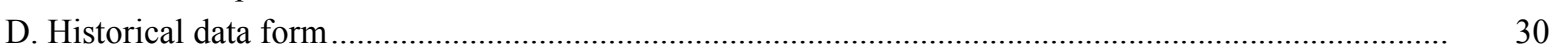

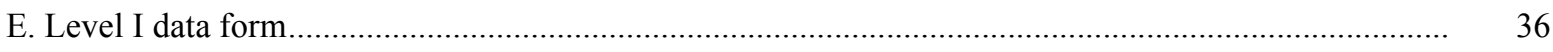

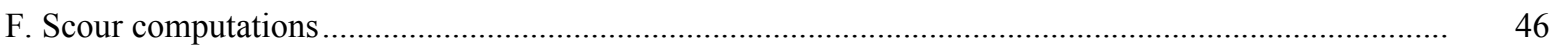

\section{FIGURES}

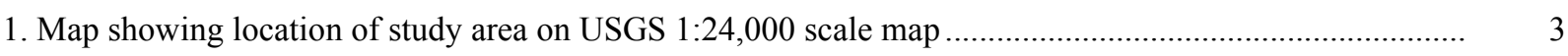

2. Map showing location of study area on Vermont Agency of Transportation town

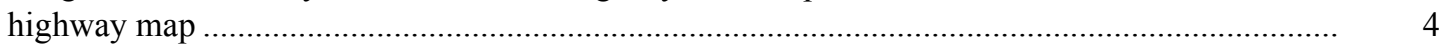

3. Structure BERLTH00600024 viewed from upstream (July 18, 1996) ................................................. 5

4. Downstream channel viewed from structure BERLTH00600024 (July 18, 1996)................................ 5

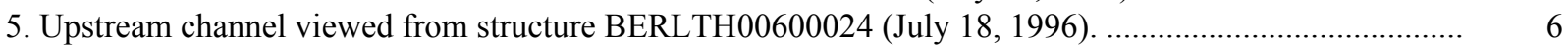

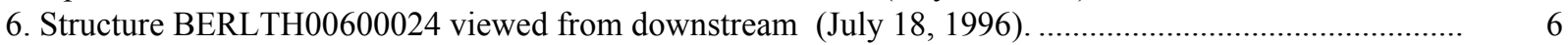

7. Water-surface profiles for the 100- and 500-year discharges at structure

BERLTH00600024 on Town Highway 60, crossing Cox Brook,

Berlin, Vermont.

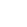

5

5

6

8. Scour elevations for the 100- and 500-year discharges at structure

BERLTH00600024 on Town Highway 60, crossing Cox Brook,

Berlin, Vermont.

\section{TABLES}

1. Remaining footing/pile depth at abutments for the 100-year discharge at structure

BERLTH00600024 on Town Highway 60, crossing Cox Brook,

Berlin, Vermont

2. Remaining footing/pile depth at abutments for the 500-year discharge at structure

BERLTH00600024 on Town Highway 60, crossing Cox Brook,

Berlin, Vermont 


\begin{tabular}{|c|c|c|}
\hline Multiply & By & To obtain \\
\hline \multicolumn{3}{|c|}{ Length } \\
\hline inch (in.) & 25.4 & millimeter (mm) \\
\hline foot $(\mathrm{ft})$ & 0.3048 & $\operatorname{meter}(\mathrm{m})$ \\
\hline mile (mi) & 1.609 & kilometer (km) \\
\hline \multicolumn{3}{|c|}{ Slope } \\
\hline foot per mile ( $\mathrm{ft} / \mathrm{mi})$ & 0.1894 & meter per kilometer $(\mathrm{m} / \mathrm{km})$ \\
\hline \multicolumn{3}{|c|}{ Area } \\
\hline square mile $\left(\mathrm{mi}^{2}\right)$ & 2.590 & square kilometer $\left(\mathrm{km}^{2}\right)$ \\
\hline \multicolumn{3}{|c|}{ Volume } \\
\hline cubic foot $\left(\mathrm{ft}^{3}\right)$ & $\begin{array}{l}0.02832 \\
\text { Velocity and Flow }\end{array}$ & cubic meter $\left(\mathrm{m}^{3}\right)$ \\
\hline foot per second $(\mathrm{ft} / \mathrm{s})$ & 0.3048 & meter per second $(\mathrm{m} / \mathrm{s})$ \\
\hline cubic foot per second $\left(\mathrm{ft}^{3} / \mathrm{s}\right)$ & 0.02832 & cubic meter per second $\left(\mathrm{m}^{3} / \mathrm{s}\right)$ \\
\hline $\begin{array}{l}\text { cubic foot per second per } \\
\text { square mile } \\
{\left[\left(\mathrm{ft}^{3} / \mathrm{s}\right) / \mathrm{mi}^{2}\right]}\end{array}$ & 0.01093 & $\begin{array}{l}\text { cubic meter per } \\
\text { second per square } \\
\text { kilometer }\left[\left(\mathrm{m}^{3} / \mathrm{s}\right) / \mathrm{km}^{2}\right]\end{array}$ \\
\hline
\end{tabular}

\section{OTHER ABBREVIATIONS}

\begin{tabular}{|c|c|c|c|}
\hline $\mathrm{BF}$ & bank full & LWW & left wingwall \\
\hline $\mathrm{cfs}$ & cubic feet per second & Max & maximum \\
\hline $\mathrm{D}_{50}$ & median diameter of bed material & $\mathrm{MC}$ & main channel \\
\hline DS & downstream & RAB & right abutment \\
\hline elev. & elevation & RABUT & face of right abutment \\
\hline $\mathrm{f} / \mathrm{p}$ & flood plain & $\mathrm{RB}$ & right bank \\
\hline $\mathrm{ft}^{2}$ & square feet & ROB & right overbank \\
\hline $\mathrm{ft} / \mathrm{ft}$ & feet per foot & RWW & right wingwall \\
\hline FEMA & Federal Emergency Management Agency & $\mathrm{TH}$ & town highway \\
\hline FHWA & Federal Highway Administration & UB & under bridge \\
\hline JCT & junction & US & upstream \\
\hline LAB & left abutment & USGS & United States Geological Survey \\
\hline LABUT & face of left abutment & VTAOT & Vermont Agency of Transportation \\
\hline LB & left bank & WSPRO & water-surface profile model \\
\hline LOB & left overbank & $\mathrm{yr}$ & year \\
\hline
\end{tabular}

In this report, the words "right" and "left" refer to directions that would be reported by an observer facing downstream. Sea level: In this report, "sea level" refers to the National Geodetic Vertical Datum of 1929-- a geodetic datum derived from a general adjustment of the first-order level nets of the United States and Canada, formerly called Sea Level Datum of 1929.

In the apendices, the above abbreviations may be combined. For example, USLB would represent upstream left bank. 


\title{
LEVEL II SCOUR ANALYSIS FOR BRIDGE 24 (BERLTH00600024) ON TOWN HIGHWAY 60, CROSSING COX BROOK, BERLIN, VERMONT
}

\author{
By James R. Degnan
}

\section{INTRODUCTION AND SUMMARY OF RESULTS}

This report provides the results of a detailed Level II analysis of scour potential at structure BERLTH00600024 on Town Highway 60 crossing Cox Brook, Berlin, Vermont (figures 18). A Level II study is a basic engineering analysis of the site, including a quantitative analysis of stream stability and scour (Federal Highway Administration, 1993). Results of a Level I scour investigation also are included in appendix E of this report. A Level I investigation provides a qualitative geomorphic characterization of the study site. Information on the bridge, gleaned from Vermont Agency of Transportation (VTAOT) files, was compiled prior to conducting Level I and Level II analyses and is found in appendix D.

The site is in the Green Mountain section of the New England physiographic province in central Vermont. The $9.26-\mathrm{mi}^{2}$ drainage area is in a predominantly rural and forested basin. In the vicinity of the study site, the surface cover is forest upstream of the bridge. Downstream of the bridge the surface cover is pasture on the left bank and brush on the right bank.

In the study area, Cox Brook has an incised, sinuous channel with a slope of approximately $0.01 \mathrm{ft} / \mathrm{ft}$, an average channel top width of $53 \mathrm{ft}$ and an average bank height of $4 \mathrm{ft}$. The channel bed material ranges from gravel to boulder with a median grain size $\left(\mathrm{D}_{50}\right)$ of 54.0 $\mathrm{mm}(0.177 \mathrm{ft})$. The geomorphic assessment at the time of the Level I and Level II site visit on July 18,1996 , indicated that the reach was stable.

The Town Highway 60 crossing of Cox Brook is a 59-ft-long, one-lane bridge consisting of one 50-foot steel-beam span (Vermont Agency of Transportation, written communication, October 13, 1995). The opening length of the structure parallel to the bridge face is $53 \mathrm{ft}$. The bridge is supported by vertical, concrete abutments and wingwalls with stone fill spillthrough slopes at the face of each abutment. The channel is skewed approximately 5 degrees to the opening while the opening-skew-to-roadway is 0 degrees. 
During the Level I assessment, a scour hole $1.5 \mathrm{ft}$ deeper than the mean thalweg depth was observed in the center of the bridge opening. Scour countermeasures at the site included type- 2 stone fill (less than 36 inches diameter) along the abutments, wingwalls, and upstream banks and type- 1 stone fill (less than 12 inches diameter) along the downstream banks. Additional details describing conditions at the site are included in the Level II Summary and appendices D and E.

Scour depths and recommended rock rip-rap sizes were computed using the general guidelines described in Hydraulic Engineering Circular 18 (Richardson and Davis, 1995). In addition, the incipient roadway-overtopping discharge was determined and analyzed as another potential worst-case scour scenario. Total scour at a highway crossing is comprised of three components: 1) long-term streambed degradation; 2) contraction scour (due to accelerated flow caused by a reduction in flow area at a bridge) and; 3 ) local scour (caused by accelerated flow around piers and abutments). Total scour is the sum of the three components. Equations are available to compute depths for contraction and local scour and a summary of the results of these computations follows.

Contraction scour for all modelled flows ranged from 0.0 to $1.3 \mathrm{ft}$. The worst-case contraction scour occurred at the incipient roadway-overtopping discharge. Abutment scour ranged from 3.0 to $6.1 \mathrm{ft}$. The worst-case left abutment scour occurred at the 500 -year discharge and the worst case right abutment scour occurred at the 500-year and incipient roadway-overtopping discharges. Additional information on scour depths and depths to armoring are included in the section titled "Scour Results". Scoured-streambed elevations, based on the calculated scour depths, are presented in tables 1 and 2. A cross-section of the scour computed at the bridge is presented in figure 8. Scour depths were calculated assuming an infinite depth of erosive material and a homogeneous particle-size distribution.

It is generally accepted that the Froehlich equation (abutment scour) gives "excessively conservative estimates of scour depths" (Richardson and Davis, 1995, p. 47). Usually, computed scour depths are evaluated in combination with other information including (but not limited to) historical performance during flood events, the geomorphic stability assessment, existing scour protection measures, and the results of the hydraulic analyses. Therefore, scour depths adopted by VTAOT may differ from the computed values documented herein. 


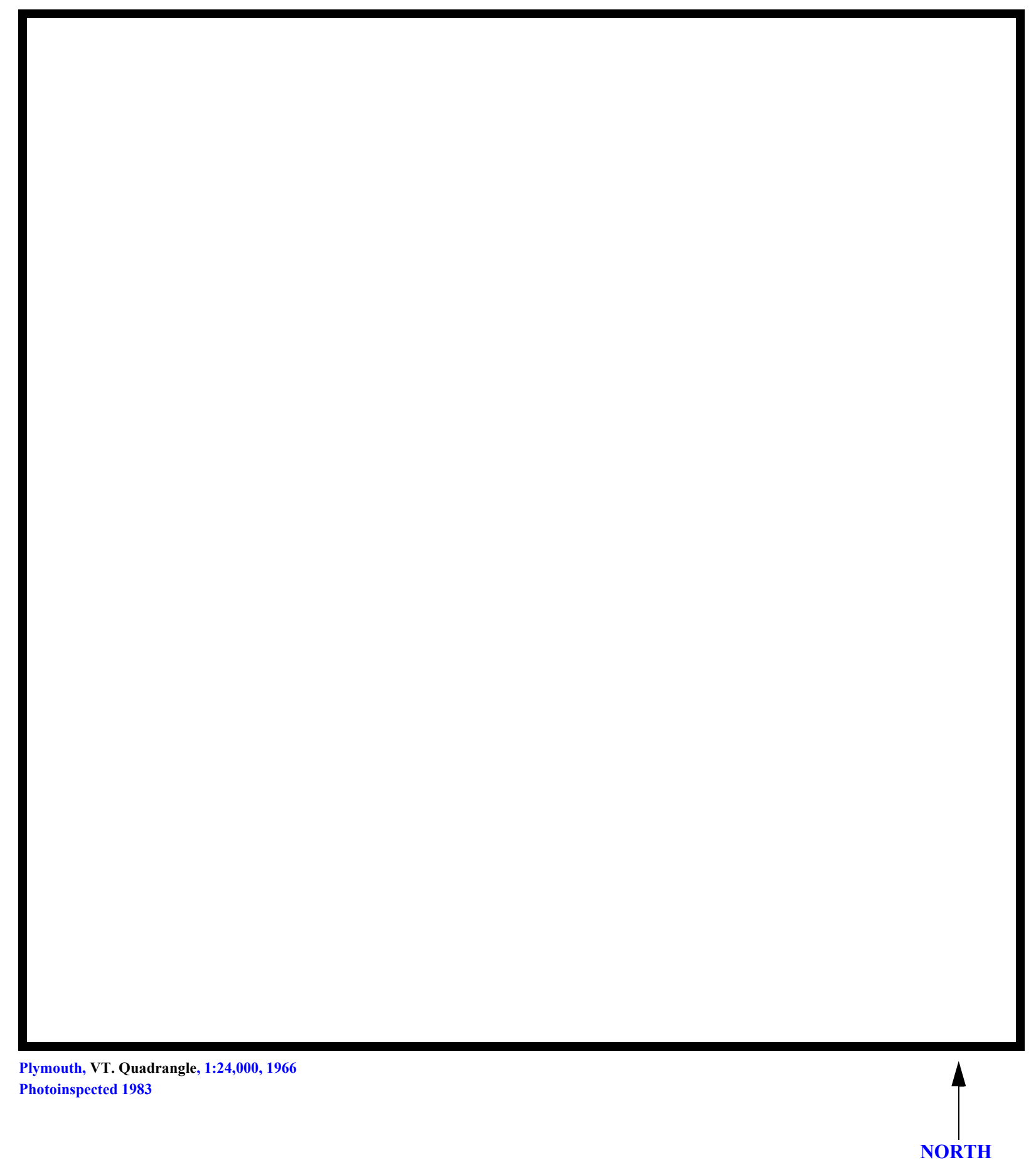

Figure 1. Location of study area on USGS 1:24,000 scale map. 
Figure 2. Location of study area on Vermont Agency of Transportation town highway map. 

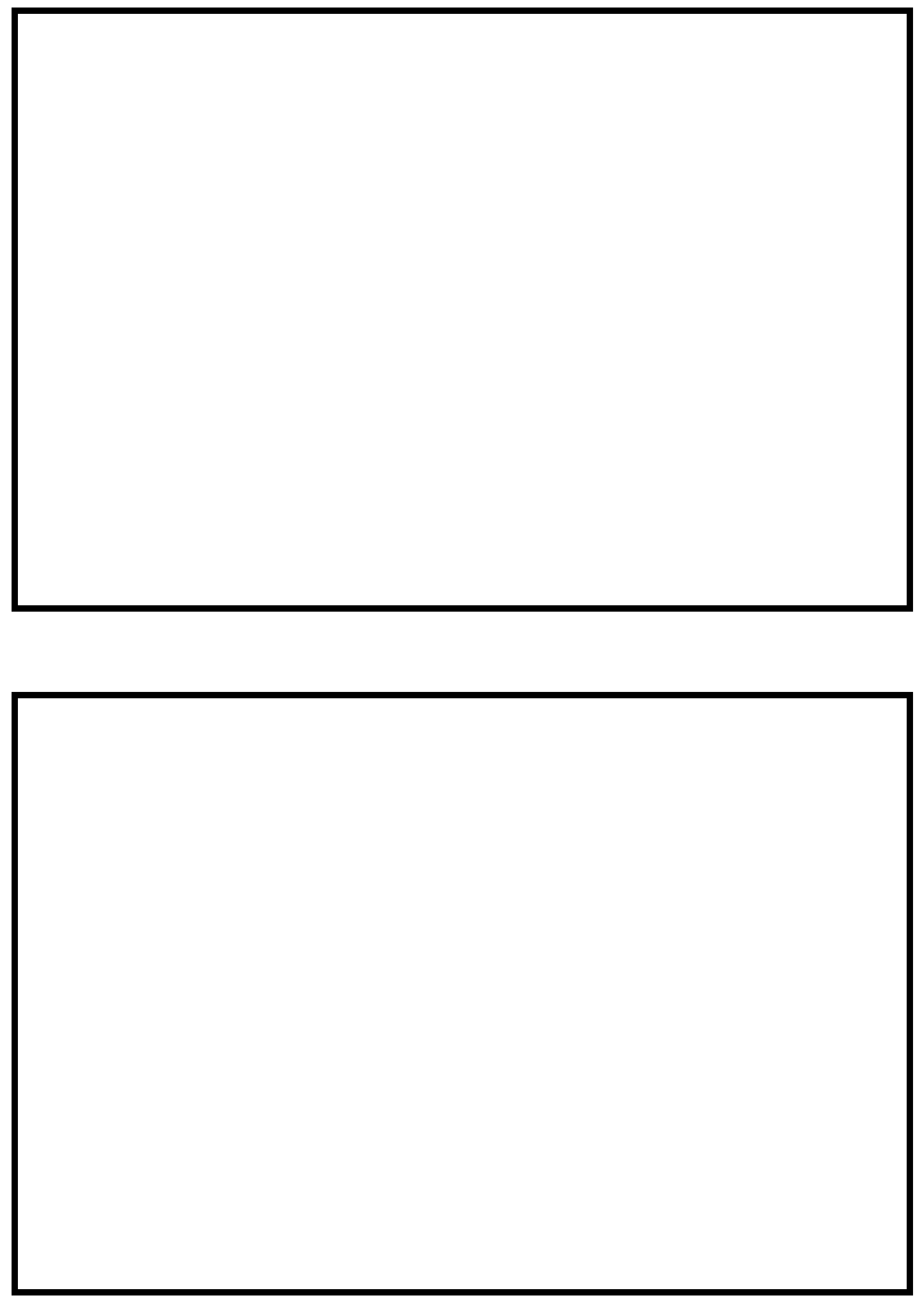

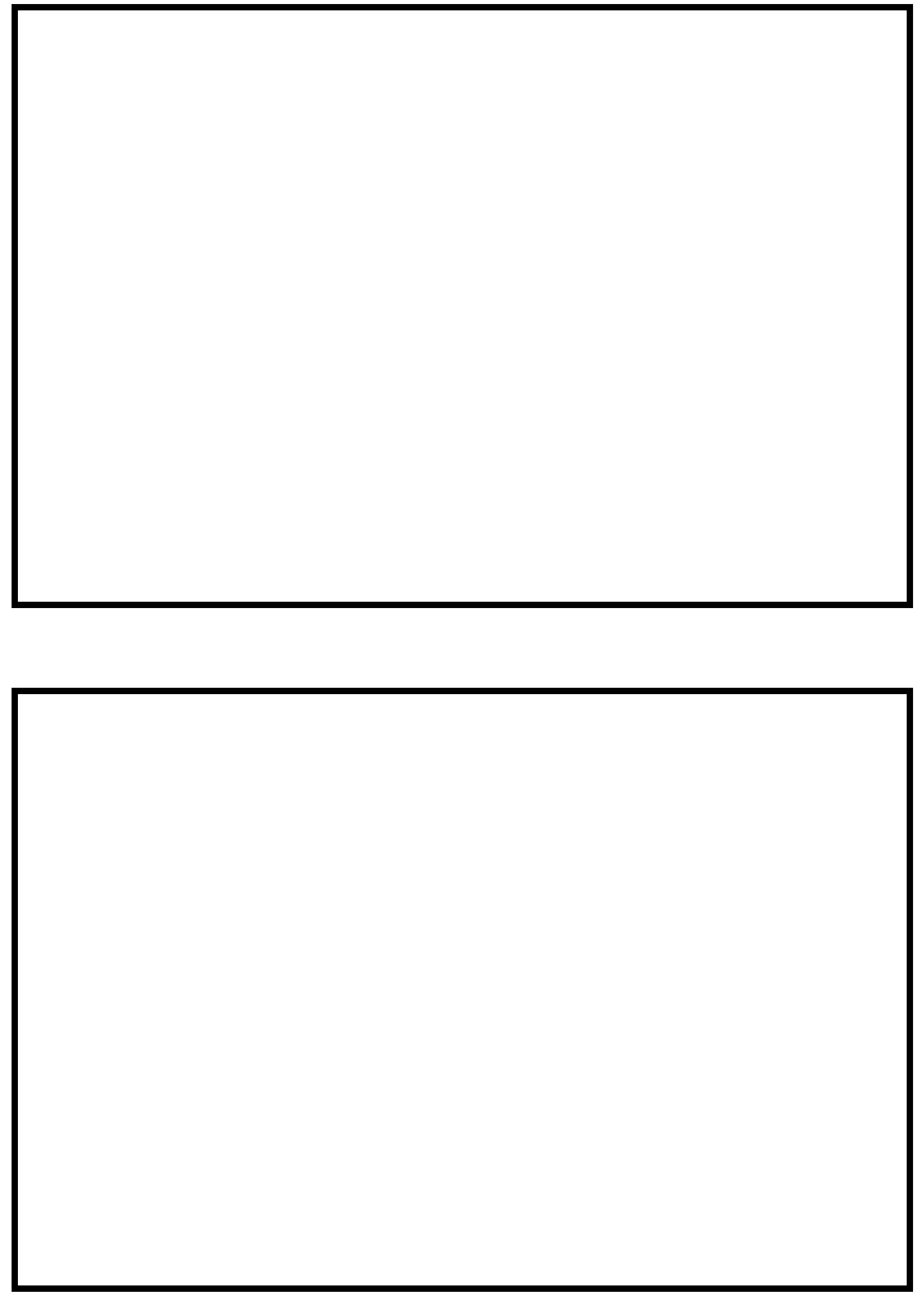


\section{LEVEL II SUMMARY}

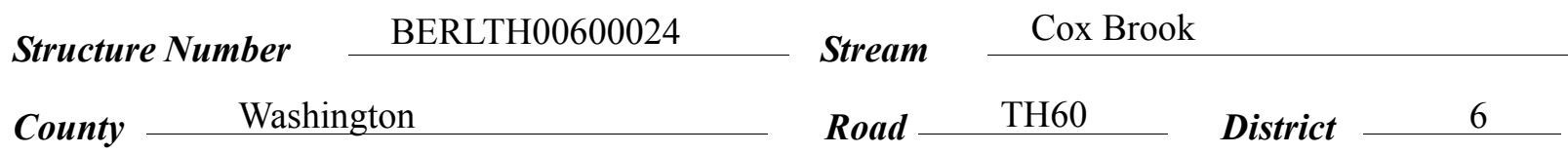

\section{Description of Bridge}

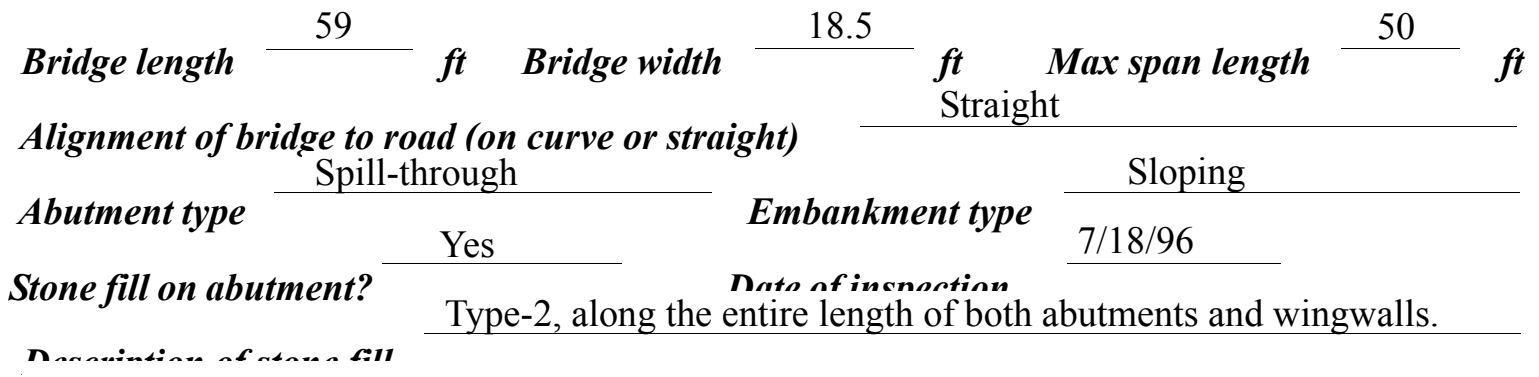

Abutments and wingwalls are concrete with stone fill spill-through slopes in front of each

abutment.

Yes

\section{5}

Is bridge skewed to flood flow according to 'survey?

Angle

Debris accumulation on bridge at time of Level I or Level II site visit:

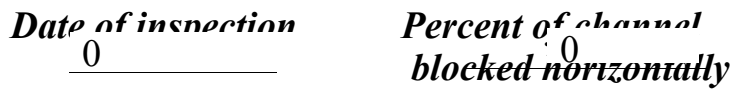

Level I

Level II

$$
\underline{96}
$$

Moderate. There is some debris caught on boulders and trees leaning over the channel upstream.

Potential for debris

Trees were observed on 7/18/96 leaning into the channel above the upstream cut banks. Dosrriho anv, fonturos noar ar at tho hridoo that mav affort flow, (includo ahsorvation dato) 


\section{Description of the Geomorphic Setting}

General topography The channel is located within a 800 foot-wide, flat to slightly irregular flood plain with steep valley walls on both sides.

Geomorphic conditions at bridge site: downstream (DS), upstream (US)

Date of inspection $\quad 7 / 18 / 96$

DS left: $\quad$ Steep channel bank to a wide flood plain and a steep valley wall

DS right: $\quad$ Steep channel bank to a narrow flood plain and a steep valley wall

US left: $\quad$ Steep channel bank to a wide flood plain and a steep valley wall

US right: $\quad$ Steep channel bank and valley wall

\section{Description of the Channel}

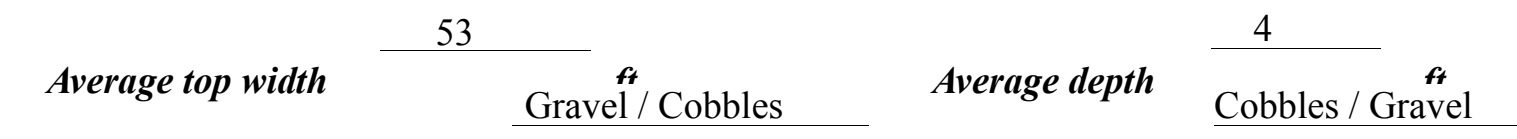

Predominant bed material

Bank material Sinuous but stable

With semi-allúvial to non-alluvial channel boundaries.

$7 / 18 / 96$

Vegetative co 1 Pasture

DS left: $\quad$ Trees and brush

DS right: Trees

US left: $\quad$ Trees

US right: $\quad$ Yes

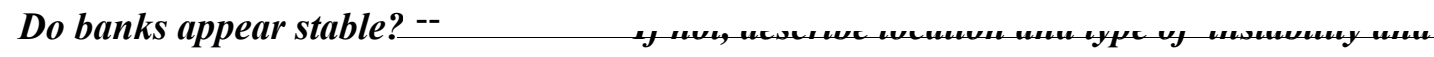

date of observatton.

None as of 7/18/96.

Describe any obstructions in channel and date of observation. 


\title{
Hydrology
}

Drainage area $\stackrel{9.26}{\boldsymbol{m i}^{2}}$

Percentage of drainage area in physiographic provinces: (approximate)

Physiographic province/section

New England/Green Mountain
Percent of drainage area 100

\begin{abstract}
Is drainage area considered rural or urban?
Rural urbanization:

Describe any significant
\end{abstract}

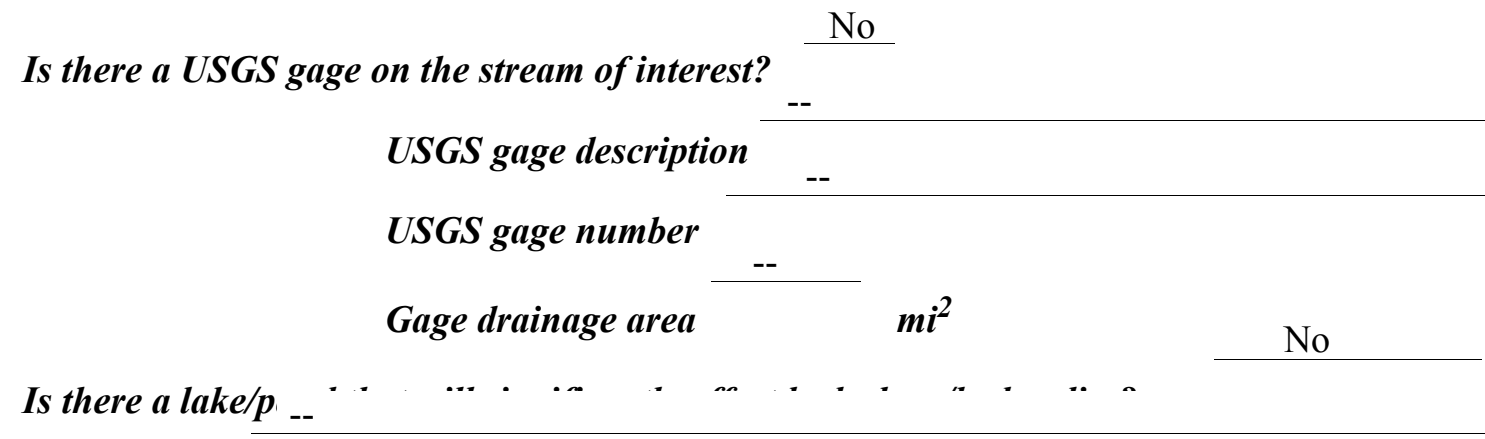

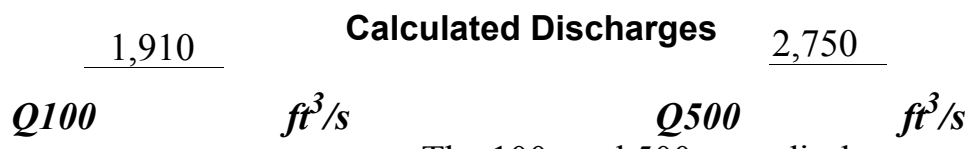

The 100- and 500-year discharges are based on a

drainage area relationship.[(9.26/6.46)exp 0.67] with bridge number 36 in Moretown. Bridge number 36 crosses Cox Brook upstream of this site and has flood frequency estimates available from the VTAOT database (Vermont Agency of Transportation, written communication, May 1995). The drainage area above bridge number 36 is 6.46 square miles. The values used were within a range defined by flood frequency curves developed from several empirical methods (Benson, 1962; Johnson and Tasker, 1974; FHWA, 1983; Potter, 1957a\&b; Talbot, 1887). 


\section{Description of the Water-Surface Profile Model (WSPRO) Analysis}

Datum for WSPRO analysis (USGS survey, sea level, VTAOT plans)

USGS survey

Datum tie between USGS survey and VTAOT plans

Add $227.4 \mathrm{ft}$ to the USGS

arbitrary survey datum to obtain the VTAOT plans' datum.

Description of reference marks used to determine USGS datum. $\quad$ RM1 is a chiseled " $X$ "

on top of the upstream right wingwall where it joins the abutment (elev. $499.47 \mathrm{ft}$, arbitrary

survey datum). RM2 is a chiseled " $X$ " on the downstream end of the left abutment (elev. 498.69

$\mathrm{ft}$, arbitrary survey datum). RM3 is a nail in a telephone pole on the upstream right bank, two

feet up (elev. $501.47 \mathrm{ft}$, arbitrary survey datum).

\section{Cross-Sections Used in WSPRO Analysis}

\begin{tabular}{ccll}
\hline${ }^{1}$ Cross-section & $\begin{array}{c}\text { Section } \\
\text { Reference } \\
\text { Distance } \\
\text { (SRD) in feet }\end{array}$ & $\begin{array}{c}{ }^{2} \text { Cross-section } \\
\text { development }\end{array}$ & \multicolumn{1}{c}{ Comments } \\
\hline EXITX & -33 & 1 & Exit section \\
FULLV & 0 & 2 & $\begin{array}{l}\text { Downstream Full-valley } \\
\text { section (Templated from } \\
\text { EXITX) }\end{array}$ \\
BRIDG & 0 & 1 & $\begin{array}{l}\text { Bridge section } \\
\text { Road Grade section }\end{array}$ \\
RDWAY & 10 & 1 & $\begin{array}{l}\text { Modelled Approach sec- } \\
\text { tion (Templated from } \\
\text { APTEM) }\end{array}$ \\
APTEM & 73 & 2 & $\begin{array}{l}\text { Approach section as sur- } \\
\text { veyed (Used as a tem- } \\
\text { plate) }\end{array}$ \\
\hline
\end{tabular}

${ }^{1}$ For location of cross-sections see plan-view sketch included with Level I field form, Appendix E. For more detail on how cross-sections were developed see WSPRO input file. 


\section{Data and Assumptions Used in WSPRO Model}

Hydraulic analyses of the reach were done by use of the Federal Highway Administration's WSPRO step-backwater computer program (Shearman and others, 1986, and Shearman, 1990). The analyses reported herein reflect conditions existing at the site at the time of the study. Furthermore, in the development of the model it was necessary to assume no accumulation of debris or ice at the site. Results of the hydraulic model are presented in the Bridge Hydraulic Summary, appendix B, and figure 7.

Channel roughness factors (Manning's " $n$ ") used in the hydraulic model were estimated using field inspections at each cross section following the general guidelines described by Arcement and Schneider (1989). Final adjustments to the values were made during the modelling of the reach. Channel " $n$ " values for the reach ranged from 0.037 to 0.052 , and overbank " $\mathrm{n}$ " values ranged from 0.035 to 0.065 .

Normal depth at the exit section (EXITX) was assumed as the starting water surface. This depth was computed by use of the slope-conveyance method outlined in the user's manual for WSPRO (Shearman, 1990). The slope used was $0.010 \mathrm{ft} / \mathrm{ft}$ which was estimated from the topographic map (U.S. Geological Survey, 1980).

The surveyed approach section (APTEM) was moved along the approach channel slope $(0.040 \mathrm{ft} / \mathrm{ft})$ to establish the modelled approach section (APPRO), one bridge length upstream of the upstream face as recommended by Shearman and others (1986). This location provides a consistent method for determining scour variables. 


\section{Bridge Hydraulics Summary}

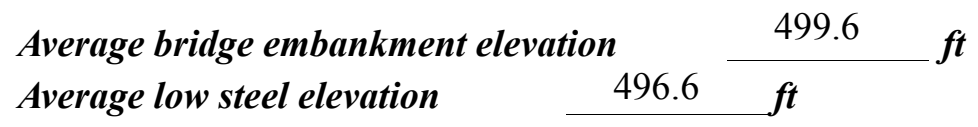

100-year discharge $\quad 1,910 \quad \mathrm{ft}^{3} / \mathrm{s}$

Water-surface elevation in bridge opening $\quad 493.0 \quad f t$

Road overtopping? ___ N Discharge over road ___ -- $\mathrm{ft}^{3} / \mathrm{s}$

Area of flow in bridge opening $\quad 169 \quad \mathrm{ft}^{2}$

Average velocity in bridge opening $\quad 11.3 \quad \mathrm{ft} / \mathrm{s}$

$\begin{array}{llll}\text { Maximum WSPRO tube velocity at bridge } & 15.0 \mathrm{ft} / \mathrm{s}\end{array}$

Water-surface elevation at Approach section with bridge 495.4

Water-surface elevation at Approach section without bridge $\quad \overline{494.8}$

Amount of backwater caused by bridge $\quad 0.6 \quad$ it

500-year discharge $\quad 2,750 \quad \mathrm{ft}^{3} / \mathrm{s}$

Water-surface elevation in bridge opening $497.0 \mathrm{ft}$

Road overtopping? ___ Y Discharge over road __ $163,{ }^{3} / \mathrm{s}$

\begin{tabular}{llll} 
Area of flow in bridge opening & $345 \quad \boldsymbol{f t}^{2}$ & \\
\cline { 2 - 3 } Average velocity in bridge opening & & $7.5 \quad \mathrm{ft} / \mathrm{s}$
\end{tabular}

Maximum WSPRO tube velocity at bridge 9.8 's

Water-surface elevation at Approach section with bridge 497.9

Water-surface elevation at Approach section without bridge $\quad 496.2$

Amount of backwater caused by bridge $\quad 1.7, t$

Incipient overtopping discharge $\quad 2,390 \quad \mathrm{ft}^{3} / \mathrm{s}$

Water-surface elevation in bridge opening $493.7 \quad t$

Area of flow in bridge opening $199 \quad \mathrm{ft}^{2}$

Average velocity in bridge opening $\quad 12.0 \quad \mathrm{ft} / \mathrm{s}$

Maximum WSPRO tube velocity at bridge $\quad 15.9 \mathrm{ft} / \mathrm{s}$

Water-surface elevation at Approach section with bridge 496.8

Water-surface elevation at Approach section without bridge $\quad 405.6$

Amount of backwater caused by bridge $\quad 1.2$, $t$ 


\section{Scour Analysis Summary}

\section{Special Conditions or Assumptions Made in Scour Analysis}

Scour depths were computed using the general guidelines described in Hydraulic Engineering Circular 18 (Richardson and Davis, 1995). Scour depths were calculated assuming an infinite depth of erosive material and a homogeneous particle-size distribution. The results of the scour analysis for the 100-year and 500-year discharges are presented in tables 1 and 2 and a graph of the scour depths is presented in figure 8 .

Contraction scour for the 100-year and incipient roadway-overtopping discharges was computed by use of the Laursen clear-water contraction scour equation (Richardson and Davis, 1995, p. 32, equation 20). At this site, the 500-year discharge resulted in unsubmerged orifice flow. Contraction scour at bridges with orifice flow is best estimated by use of the Chang pressure-flow scour equation (oral communication, J. Sterling Jones, October 4, 1996). Thus, contraction scour for this discharge was computed by use of the Chang equation (Richardson and Davis, 1995, p. 145-146). The streambed armoring depths computed suggest that armoring will not limit the depth of contraction scour.

For the 500-year discharge, estimates of contraction scour were also computed by use of the Laursen clear-water contraction scour equation and the Umbrell pressure-flow equation (Richardson and Davis, 1995, p. 144) and are presented in appendix F. Furthermore, for the 500-year discharge, contraction scour was computed by substituting an estimate for the depth of flow at the downstream bridge face in the contraction scour equations. Results with respect to this substitution are provided in appendix F.

Scour for the right abutment was computed by use of the Froehlich equation (Richardson and Davis, 1995, p. 48, equation 28). Variables for the Froehlich equation include the Froude number of the flow approaching the embankments, the length of the embankment blocking flow, and the depth of flow approaching the embankment less any roadway overtopping.

Scour at the left abutment was computed by use of the HIRE equation (Richardson and Davis, 1995, p. 49, equation 29) because the HIRE equation is recommended when the length to depth ratio of the embankment blocking flow exceeds 25 . The variables used by the HIRE abutment-scour equation are defined the same as those defined for the Froehlich abutment-scour equation.

Because the influence of scour processes on the material of spill-through embankments is uncertain, the scour depth at the vertical concrete abutment walls is unknown. Therefore, the total scour depth computed at the toe of the embankment was applied for the entire spill-through embankment as shown in figure 8 . 


\section{Scour Results}

100-yr discharge 500-yrdischarge

Incipient

Contraction scour:

(Scour depths in feet)

Main channel

Live-bed scour

overtopping

discharge

Clear-water scour

Depth to armoring

Left overbank

Right overbank

Local scour:
Abutment scour

Left abutment

Right abutment

Pier scour

Pier 1

Pier 2

Pier 3
3.8

4.9-
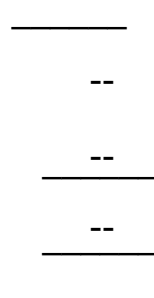

$\longrightarrow$
4.4

$6.1-$
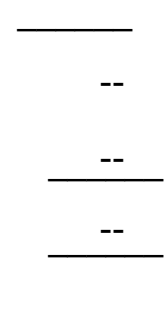

3.0

6.1-

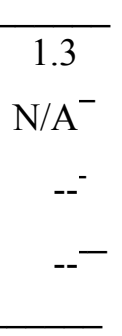

Riprap Sizing

Incipient overtopping 100-yr discharge 500-yrdischarge discharge

$$
\text { ( } D_{50} \text { in feet) }
$$

1.5

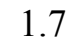

1.7
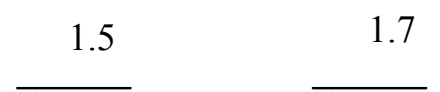

1.7

Left abutment

Right abutment

Piers:

Pier 1

Pier 2

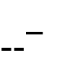

$--$

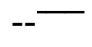

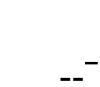

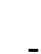




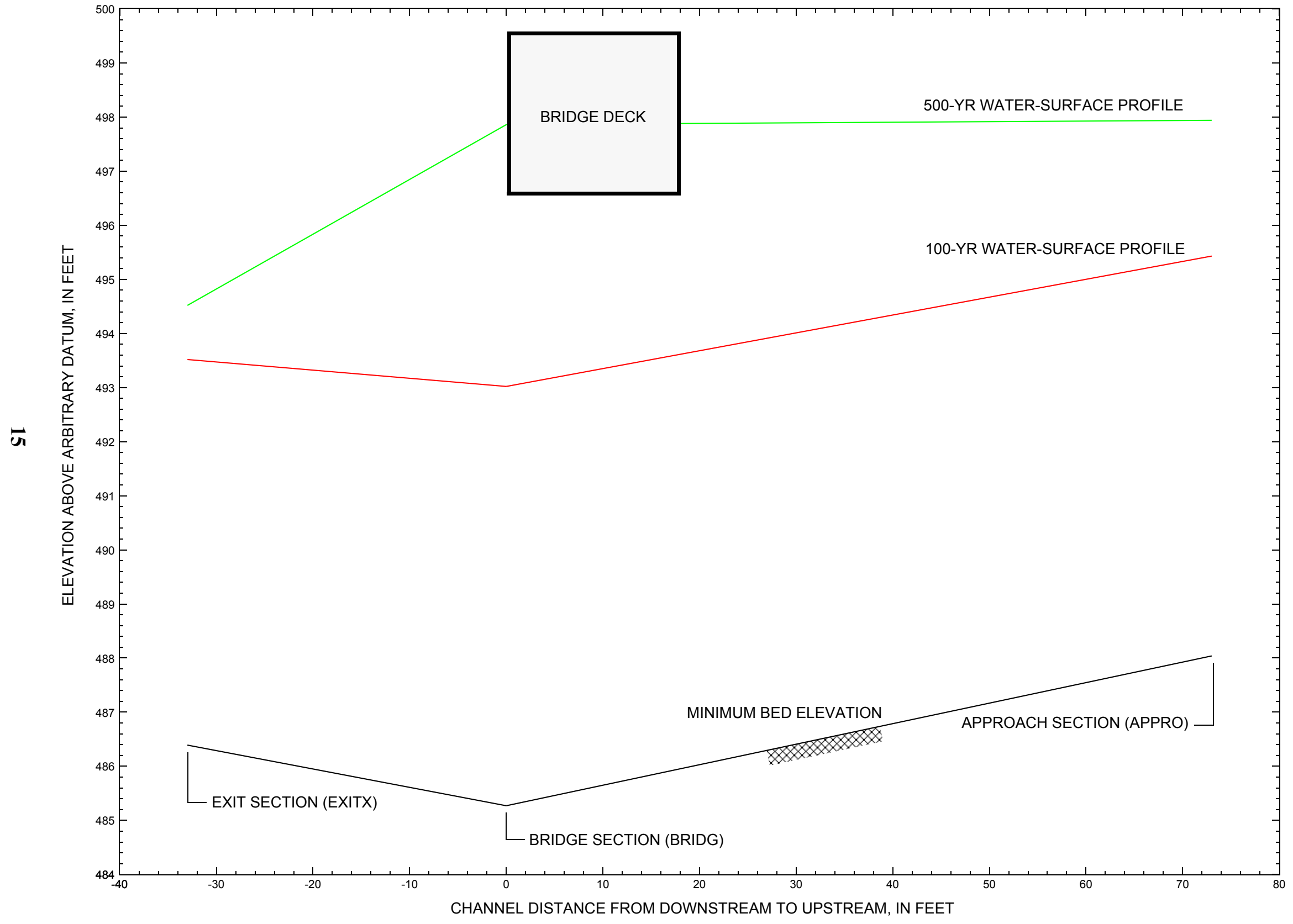

Figure 7. Water-surface profiles for the 100- and 500-yr discharges at structure BERLTH00600024 on Town Highway 60, crossing Cox Brook, Berlin, Vermont. 


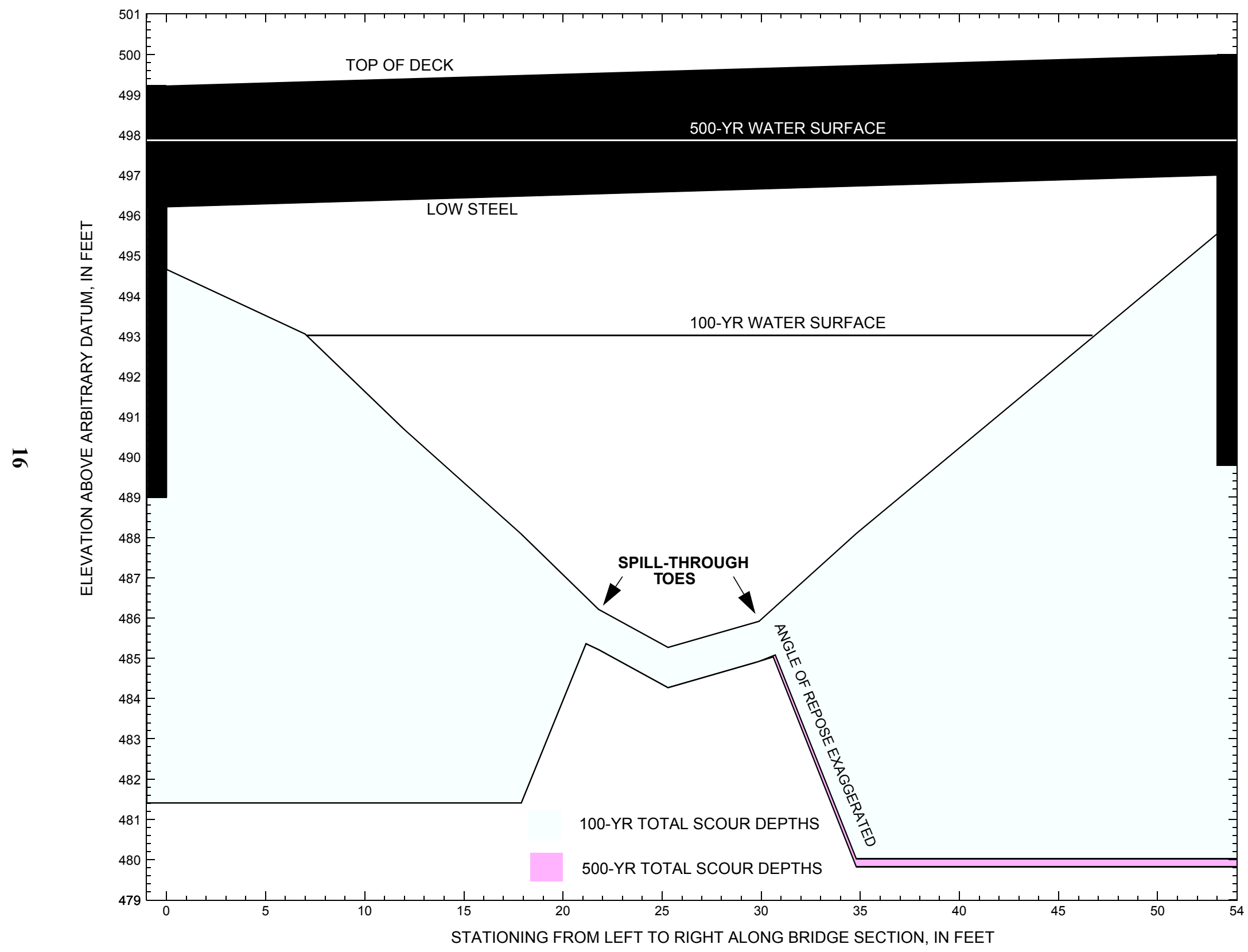

Figure 8. Scour elevations for the 100-yr and 500-yr discharges at structure BERLTH00600024 on Town Highway 60, crossing Cox Brook, Berlin, Vermont. 
Table 1. Remaining footing/pile depth at abutments for the 100-yr discharge at structure BERLTH00600024 on Town Highway 60, crossing Cox Brook, Berlin, Vermont. [VTAOT, Vermont Agency of Transportation; --,no data]

\begin{tabular}{|c|c|c|c|c|c|c|c|c|c|c|c|}
\hline Description & Station $^{1}$ & $\begin{array}{l}\text { VTAOT } \\
\text { minimum } \\
\text { bridge seat } \\
\text { elevation } \\
\text { (feet) }\end{array}$ & $\begin{array}{l}\text { Surveyed } \\
\text { minimum } \\
\text { low-chord } \\
\text { elevation } \\
\text { (feet) }\end{array}$ & $\begin{array}{l}\text { Bottom of } \\
\text { footing } \\
\text { elevation } \\
\text { (feet) }\end{array}$ & $\begin{array}{c}\text { Channel } \\
\text { elevation at } \\
\text { abutment/ } \\
\text { pier }^{2} \\
\text { (feet) }\end{array}$ & $\begin{array}{l}\text { Contraction } \\
\text { scour depth } \\
\text { (feet) }\end{array}$ & $\begin{array}{l}\text { Abutment } \\
\text { scour } \\
\text { depth } \\
\text { (feet) }\end{array}$ & $\begin{array}{l}\text { Pier } \\
\text { scour } \\
\text { depth } \\
\text { (feet) }\end{array}$ & $\begin{array}{l}\text { Depth of } \\
\text { total scour } \\
\text { (feet) }\end{array}$ & $\begin{array}{c}\text { Elevation of } \\
\text { scour }^{2} \\
\text { (feet) }\end{array}$ & $\begin{array}{c}\text { Remaining } \\
\text { footing/pile } \\
\text { depth } \\
\text { (feet) }\end{array}$ \\
\hline \multicolumn{12}{|c|}{100 -yr. discharge is 1,910 cubic-feet per second } \\
\hline Left abutment & 0.0 & 773.4 & 496.2 & 489.0 & 494.7 & -- & -- & -- & -- & -- & -7.6 \\
\hline LABUT toe & 21.8 & -- & -- & -- & 486.2 & 1.0 & 3.8 & -- & 4.8 & 481.4 & -- \\
\hline RABUT toe & 29.9 & -- & -- & -- & 485.9 & 1.0 & 4.9 & -- & 5.9 & 480.0 & -- \\
\hline Right abutment & 53.0 & 774.2 & 497.0 & 489.8 & 495.5 & -- & -- & -- & -- & -- & -9.8 \\
\hline
\end{tabular}

1.Measured along the face of the most constricting side of the bridge.

2.Arbitrary datum for this study.

Table 2. Remaining footing/pile depth at abutments for the 500-yr discharge at structure BERLTH00600024 on Town Highway 60, crossing Cox Brook, Berlin, Vermont. [VTAOT, Vermont Agency of Transportation; --, no data]

\begin{tabular}{|c|c|c|c|c|c|c|c|c|c|c|c|}
\hline Description & Station $^{1}$ & $\begin{array}{l}\text { VTAOT } \\
\text { minimum } \\
\text { bridge seat } \\
\text { elevation } \\
\text { (feet) }\end{array}$ & $\begin{array}{c}\text { Surveyed } \\
\text { minimum } \\
\text { low-chord } \\
\text { elevation } \\
\text { (feet) }\end{array}$ & $\begin{array}{c}\text { Bottom of } \\
\text { footing } \\
\text { elevation } \\
\text { (feet) }\end{array}$ & $\begin{array}{c}\text { Channel } \\
\text { elevation at } \\
\text { abutment/ } \\
\text { pier }^{2} \\
\text { (feet) }\end{array}$ & $\begin{array}{l}\text { Contraction } \\
\text { scour depth } \\
\text { (feet) }\end{array}$ & $\begin{array}{l}\text { Abutment } \\
\text { scour } \\
\text { depth } \\
\text { (feet) }\end{array}$ & $\begin{array}{l}\text { Pier } \\
\text { scour } \\
\text { depth } \\
\text { (feet) }\end{array}$ & $\begin{array}{l}\text { Depth of } \\
\text { total scour } \\
\text { (feet) }\end{array}$ & $\begin{array}{c}\text { Elevation of } \\
\text { scour }^{2} \\
\text { (feet) }\end{array}$ & $\begin{array}{c}\text { Remaining } \\
\text { footing/pile } \\
\text { depth } \\
\text { (feet) }\end{array}$ \\
\hline \multicolumn{12}{|c|}{500 -yr. discharge is 2,750 cubic-feet per second } \\
\hline Left abutment & 0.0 & 773.4 & 496.2 & 489.0 & 494.7 & -- & -- & -- & -- & -- & -7.2 \\
\hline LABUT toe & 21.8 & -- & -- & -- & 486.2 & 0.0 & 4.4 & -- & 4.4 & 481.8 & -- \\
\hline RABUT toe & 29.9 & -- & -- & -- & 485.9 & 0.0 & 6.1 & -- & 6.1 & 479.8 & -- \\
\hline Right abutment & 53.0 & 774.2 & 497.0 & 489.8 & 495.5 & -- & -- & -- & -- & -- & -10.0 \\
\hline
\end{tabular}

1.Measured along the face of the most constricting side of the bridge.

2.Arbitrary datum for this study. 


\section{SELECTED REFERENCES}

Arcement, G.J., Jr., and Schneider, V.R., 1989, Guide for selecting Manning's roughness coefficients for natural channels and flood plains: U.S. Geological Survey Water-Supply Paper 2339, 38 p.

Barnes, H.H., Jr., 1967, Roughness characteristics of natural channels: U.S. Geological Survey Water-Supply Paper 1849,213 p.

Benson, M. A., 1962, Factors Influencing the Occurrence of Floods in a Humid Region of Diverse Terrain: U.S. Geological Survey WaterSupply Paper 1580-B, 64 p.

Brown, S.A. and Clyde, E.S., 1989, Design of riprap revetment: Federal Highway Administration Hydraulic Engineering Circular No. 11, Publication FHWA-IP-89-016, 156 p.

Federal Highway Administration, 1983, Runoff estimates for small watersheds and development of sound design: Federal Highway Administration Report FHWA-RD-77-158.

Federal Highway Administration, 1993, Stream Stability and Scour at Highway Bridges: Participant Workbook: Federal Highway Administration Report FHWA-HI-91-011.

Federal Emergency Management Agency, 1980, Flood Insurance Study, Town of Berlin, Windsor County, Vermont: Washington, D.C., January 1980.

Froehlich, D.C., 1989, Local scour at bridge abutments in Ports, M.A., ed., Hydraulic Engineering--Proceedings of the 1989 National Conference on Hydraulic Engineering: New York, American Society of Civil Engineers, p. 13-18.

Hayes, D.C.,1993, Site selection and collection of bridge-scour data in Delaware, Maryland, and Virginia: U.S. Geological Survey WaterResources Investigation Report 93-4017, 23 p.

Interagency Advisory Committee on Water Data, 1982, Guidelines for determining flood flow frequency: U.S. Geological Survey, Bulletin 17B of the Hydrology Subcommittee, 190 p.

Johnson, C.G. and Tasker, G.D.,1974, Progress report on flood magnitude and frequency of Vermont streams: U.S. Geological Survey OpenFile Report 74-130, 37 p.

Lagasse, P.F., Schall, J.D., Johnson, F., Richardson, E.V., Chang, F., 1995, Stream Stability at Highway Structures: Federal Highway Administration Hydraulic Engineering Circular No. 20, Publication FHWA-IP-90-014, 144 p.

Laursen, E.M., 1960, Scour at bridge crossings: Journal of the Hydraulics Division, American Society of Civil Engineers, v. 86, no. HY2, p. 39-53.

Potter, W. D., 1957a, Peak rates of runoff in the Adirondack, White Mountains, and Maine woods area, Bureau of Public Roads

Potter, W. D., 1957b, Peak rates of runoff in the New England Hill and Lowland area, Bureau of Public Roads

Richardson, E.V. and Davis, S.R., 1995, Evaluating scour at bridges: Federal Highway Administration Hydraulic Engineering Circular No. 18, Publication FHWA-IP-90-017, 204 p.

Richardson, E.V., Simons, D.B., and Julien, P.Y., 1990, Highways in the river environment: Federal Highway Administration Publication FHWA-HI-90-016.

Ritter, D.F., 1984, Process Geomorphology: W.C. Brown Co., Debuque, Iowa, 603 p.

Shearman, J.O., 1990, User's manual for WSPRO--a computer model for water surface profile computations: Federal Highway Administration Publication FHWA-IP-89-027, 187 p.

Shearman, J.O., Kirby, W.H., Schneider, V.R., and Flippo, H.N., 1986, Bridge waterways analysis model; research report: Federal Highway Administration Publication FHWA-RD-86-108, 112 p.

Talbot, A.N., 1887, The determination of water-way for bridges and culverts.

U.S. Geological Survey, 1980, Northfield, Vermont 7.5 Minute Series quadrangle map: U.S. Geological Survey Topographic Maps, Photoinspected 1983, Scale 1:24,000. 


\section{APPENDIX A: \\ WSPRO INPUT FILE}


WSPRO INPUT FILE

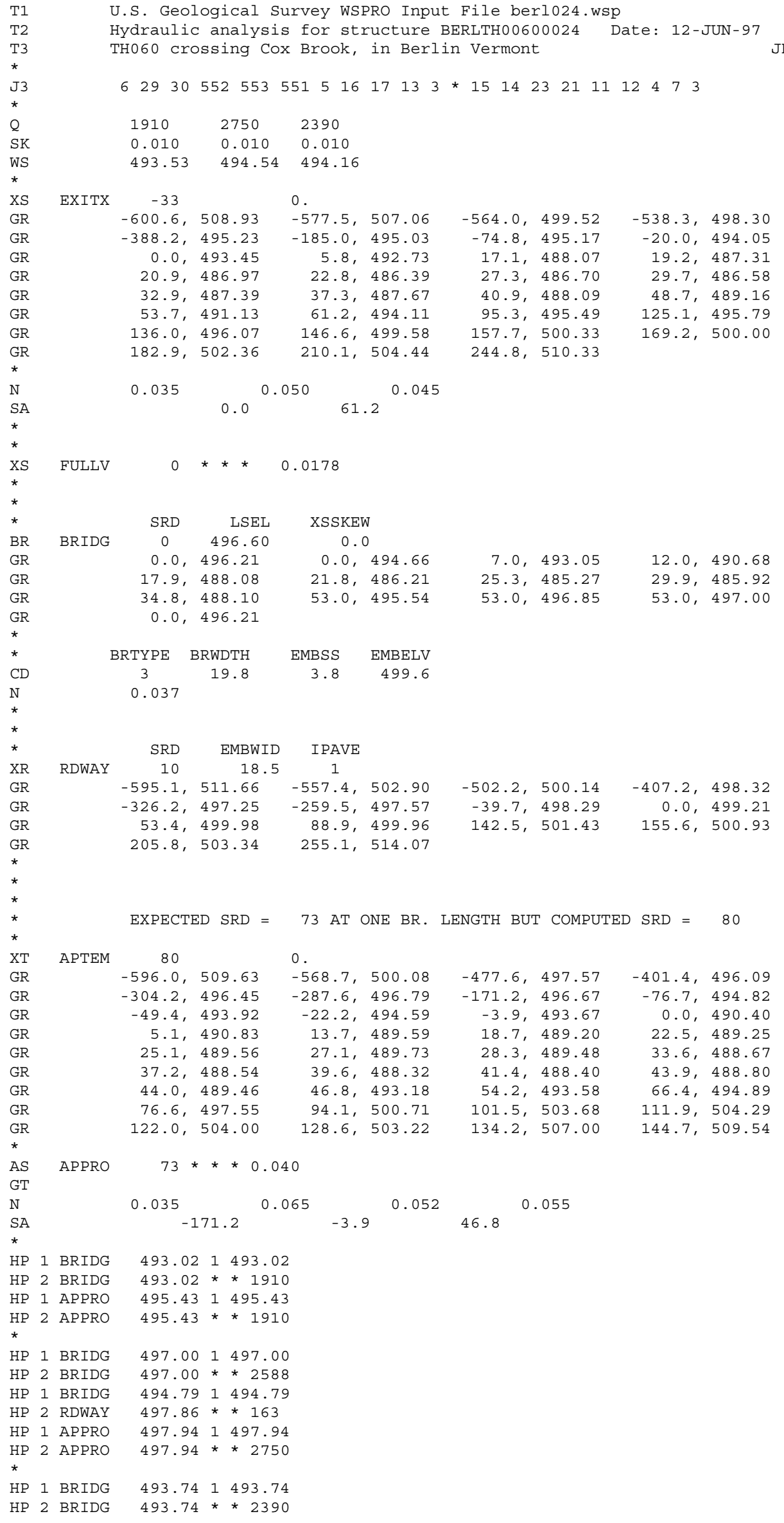




\section{APPENDIX B: \\ WSPRO OUTPUT FILE}


WSPRO OUTPUT FILE

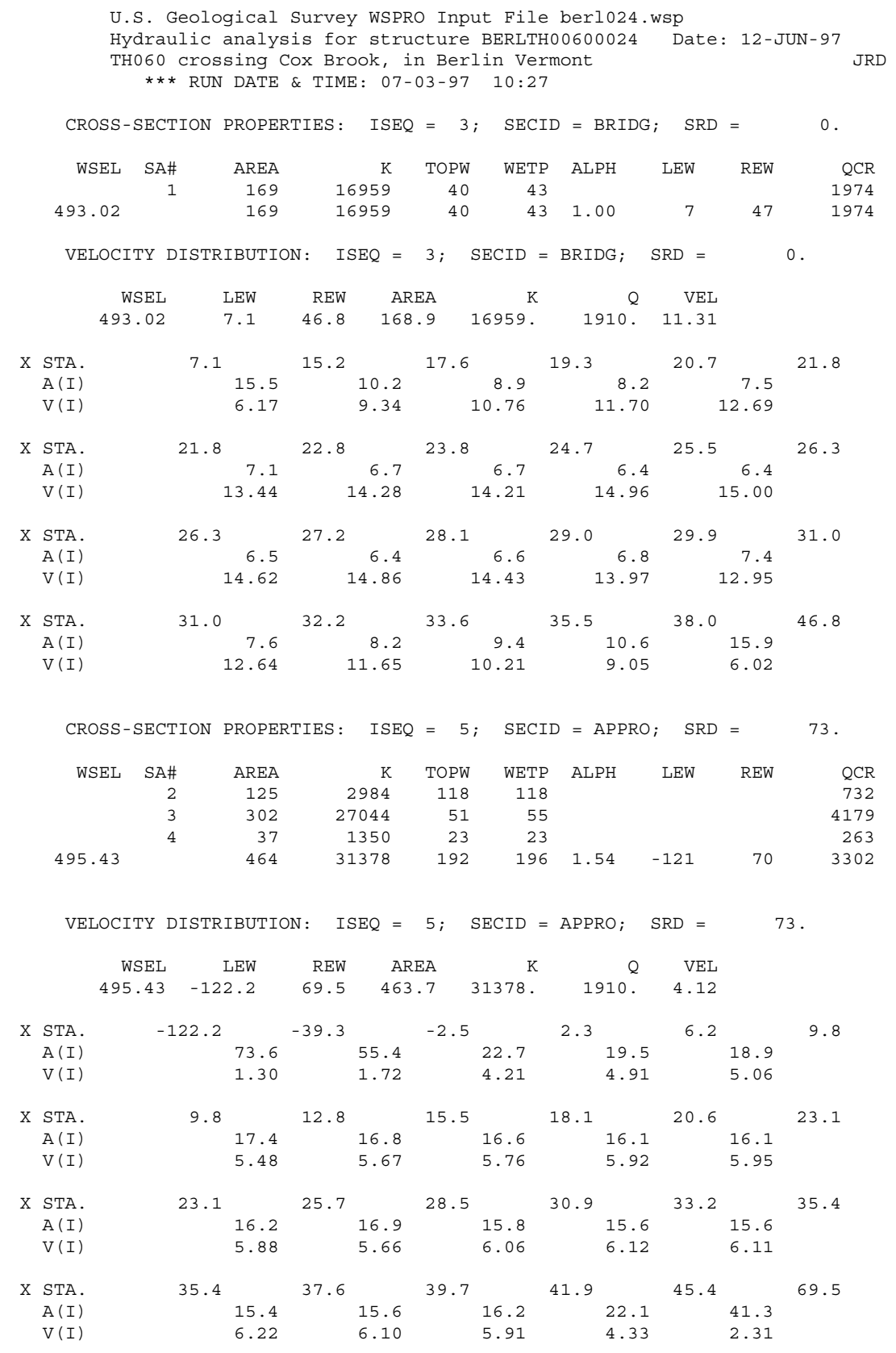


WSPRO OUTPUT FILE (continued)

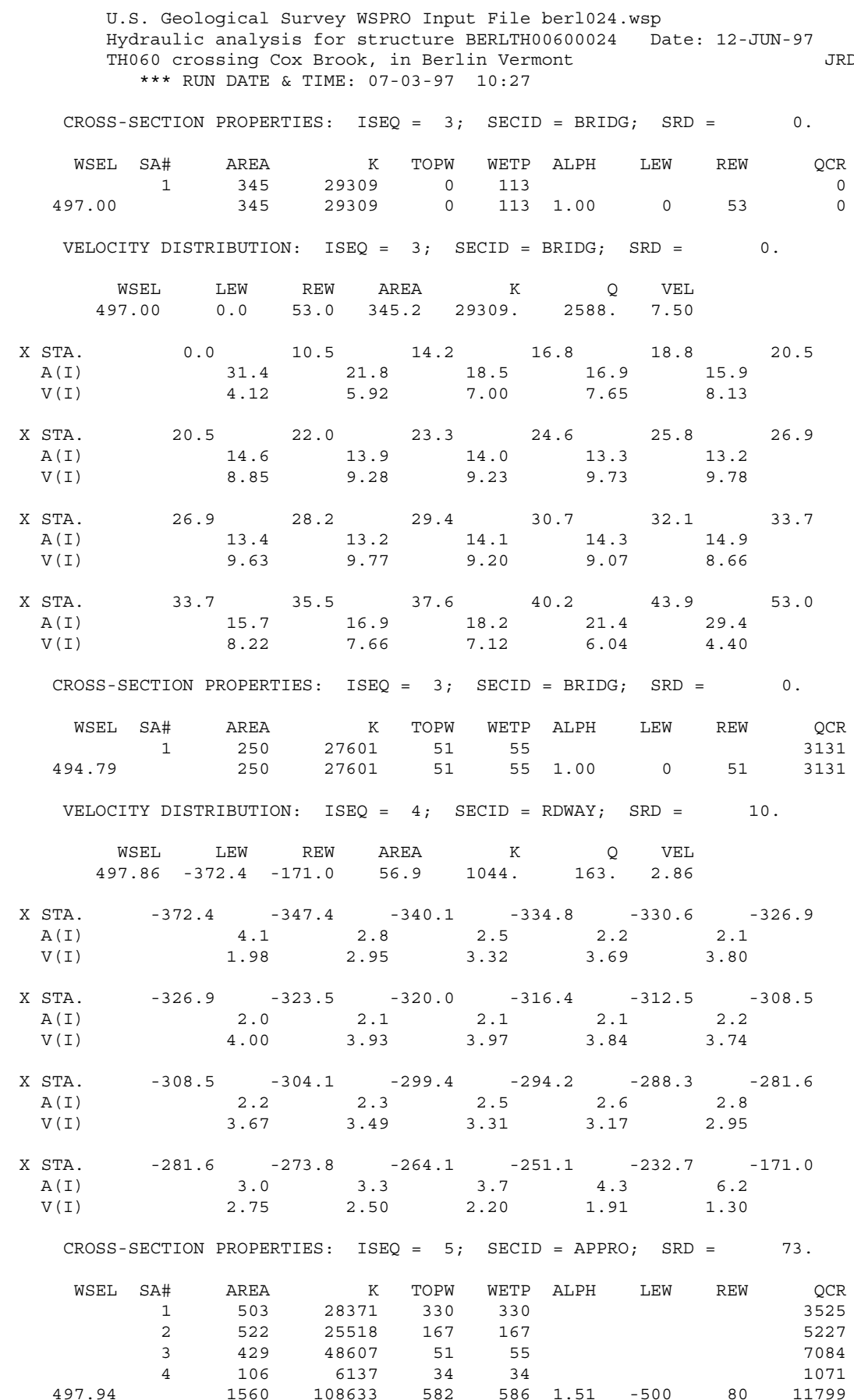

VELOCITY DISTRIBUTION: ISEQ $=5 ;$ SECID $=$ APPRO; SRD $=73$.

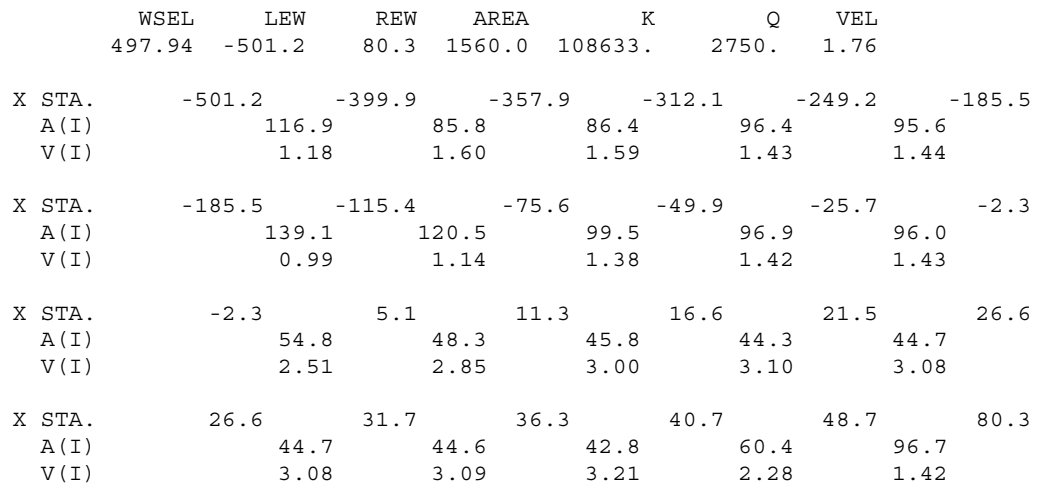


WSPRO OUTPUT FILE (continued)

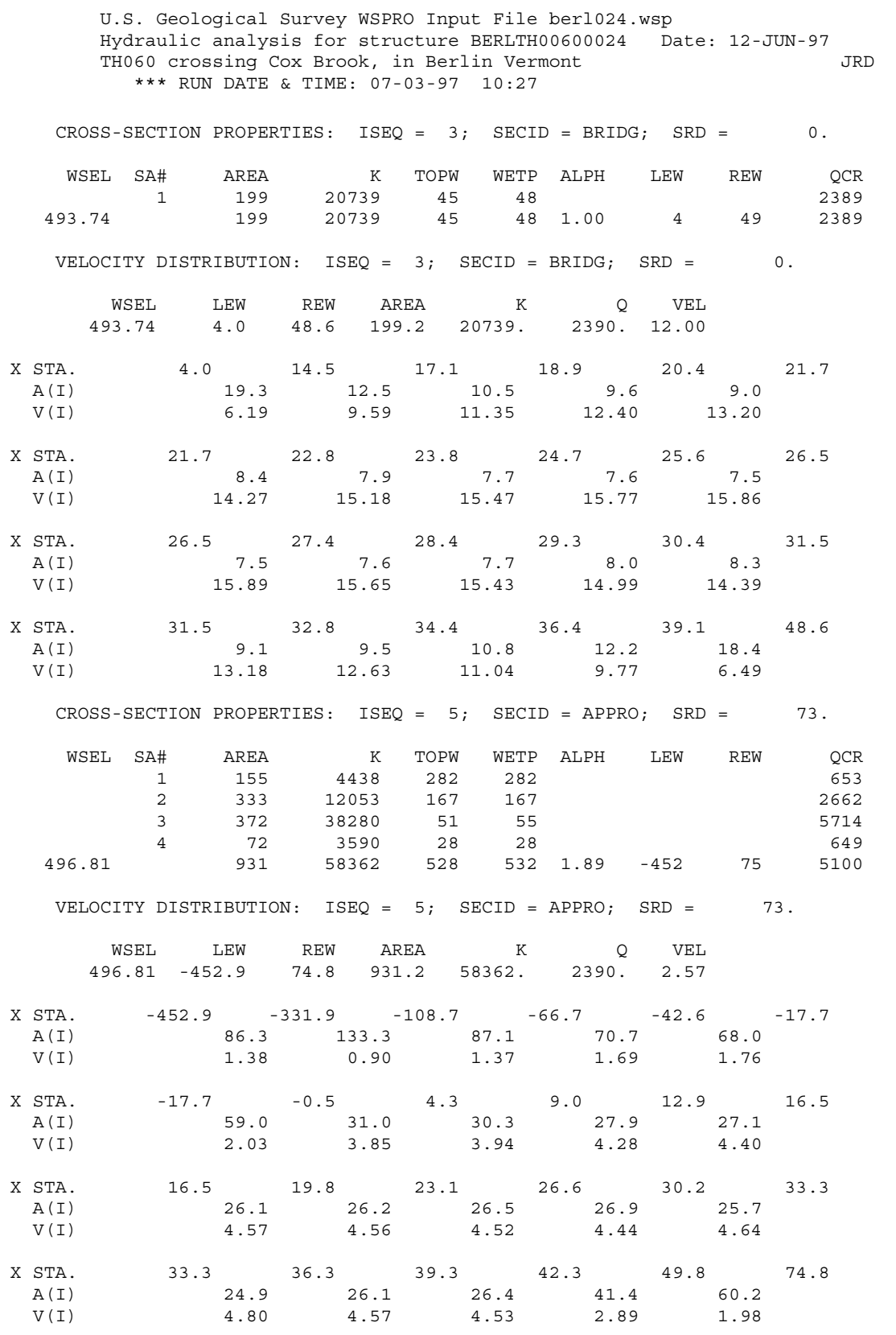


WSPRO OUTPUT FILE (continued)

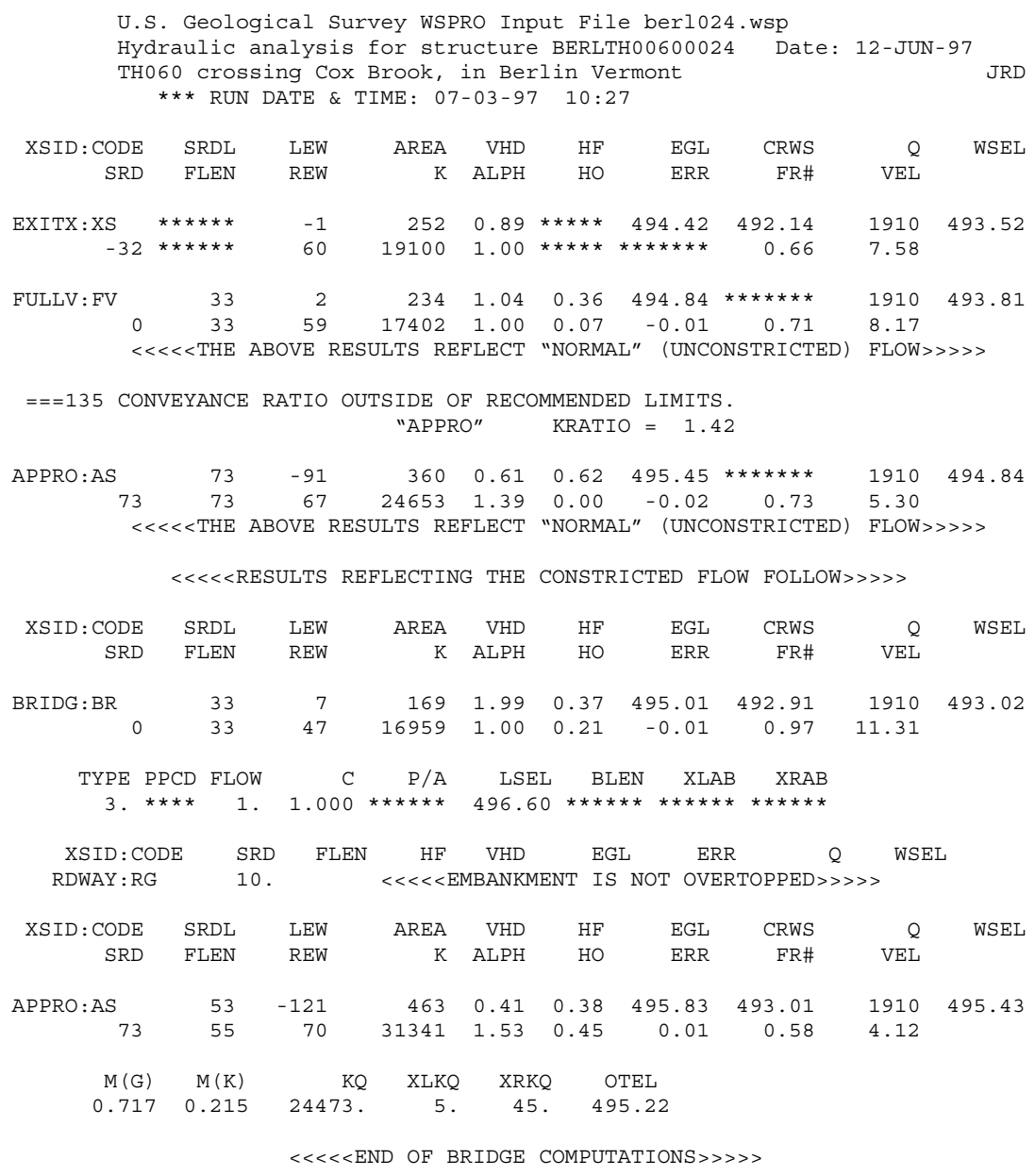

FIRST USER DEFINED TABLE.

\begin{tabular}{|c|c|c|c|c|c|c|c|c|}
\hline XSID : CODE & SRD & LEW & REW & $Q$ & $\mathrm{~K}$ & AREA & VEL & WSEL \\
\hline EXITX:XS & -33 . & -2 . & 60. & 1910. & 19100. & 252. & 7.58 & 493.52 \\
\hline FULLV: FV & 0 . & 2 . & 59. & 1910. & 17402 . & 234. & 8.17 & 493.81 \\
\hline BRIDG : BR & 0 . & 7. & 47 . & 1910. & 16959. & 169. & 11.31 & 493.02 \\
\hline RDWAY : RG & \multicolumn{3}{|c|}{$10 . * * * * * * * * * * * * * *$} & \multicolumn{3}{|c|}{ 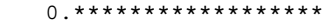 } & \multicolumn{2}{|c|}{$1.00 * * * * * * * *$} \\
\hline APPRO : AS & 73 . & -122. & 70 . & 1910. & 31341 . & 463. & 4.12 & 495.43 \\
\hline XSID : CODE & XLKQ & XRKQ & & & & & & \\
\hline APPRO : AS & 5. & & & & & & & \\
\hline
\end{tabular}

SECOND USER DEFINED TABLE.

\begin{tabular}{|c|c|c|c|c|c|c|c|c|c|}
\hline XSII & RWS & FR\# & YMIN & YMAX & $\mathrm{HF}$ & $\mathrm{HO}$ & VHD & EGL & \\
\hline EXITX:XS & 492.14 & 0.66 & 486.39 & $110.33 *$ & $\star \star \star$ & $* * *$ & 0.89 & 494.42 & 493.52 \\
\hline ULI & $* * *$ & 71 & 86. & 510.92 & 0.36 & 0.07 & 1.04 & 84 & $=9$ \\
\hline KI & 492.91 & .97 & & 497.00 & 0.37 & 0.21 & 1.99 & 495.01 & 493. \\
\hline & $\star \star \star \star \star \star \star \star \star$ & 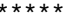 & 497.25 & $514.07 *$ & 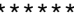 & & $\star \star \star \star \star \star ~$ & $\star \star \star \star \star \star \star \star \star$ & $\star \star \star \star \star$ \\
\hline & 493 & 0.58 & 88.04 & 09.35 & 0.38 & 0.45 & 0.41 & 495.83 & 49 \\
\hline
\end{tabular}


WSPRO OUTPUT FILE (continued)

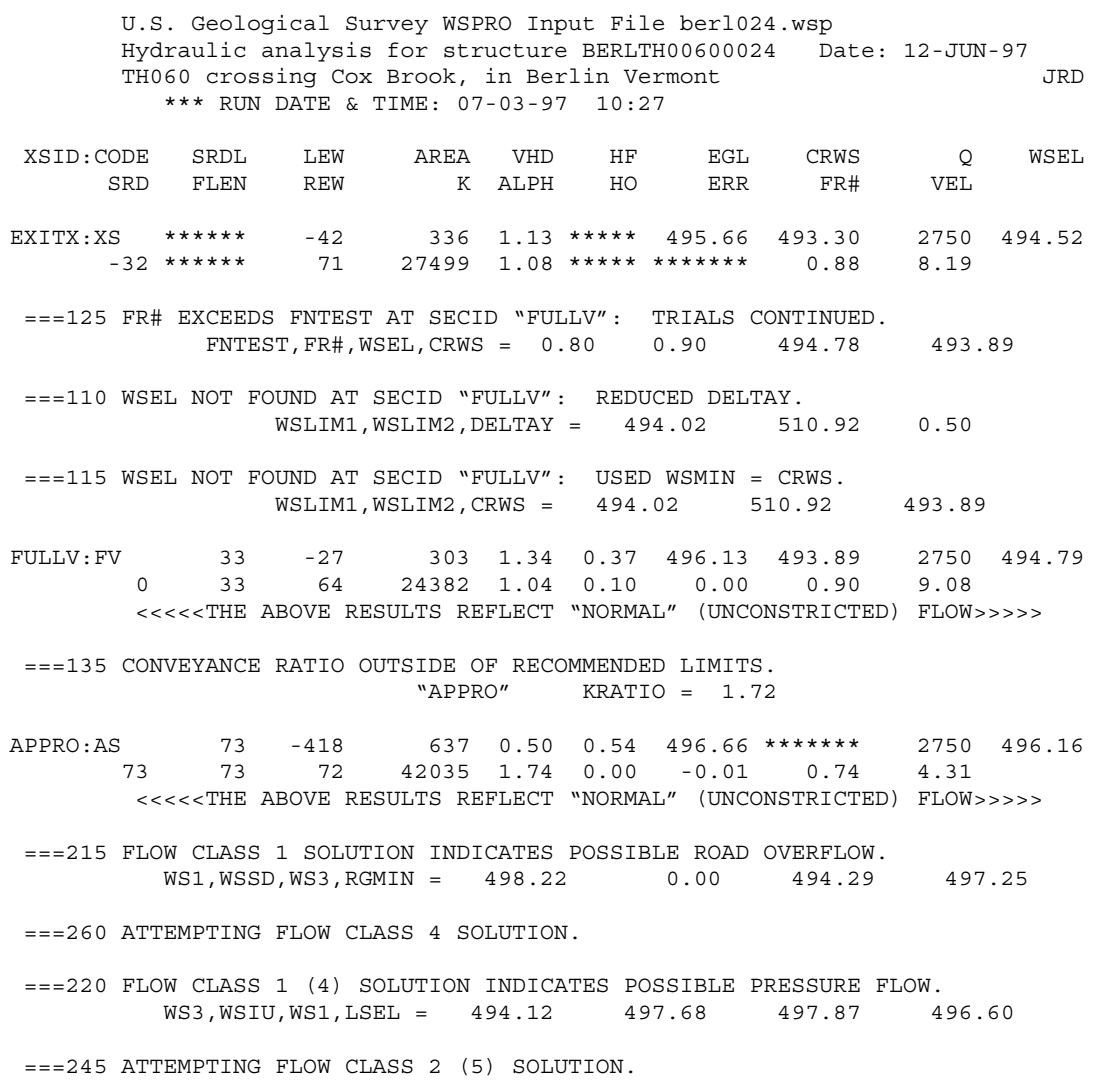


WSPRO OUTPUT FILE (continued)

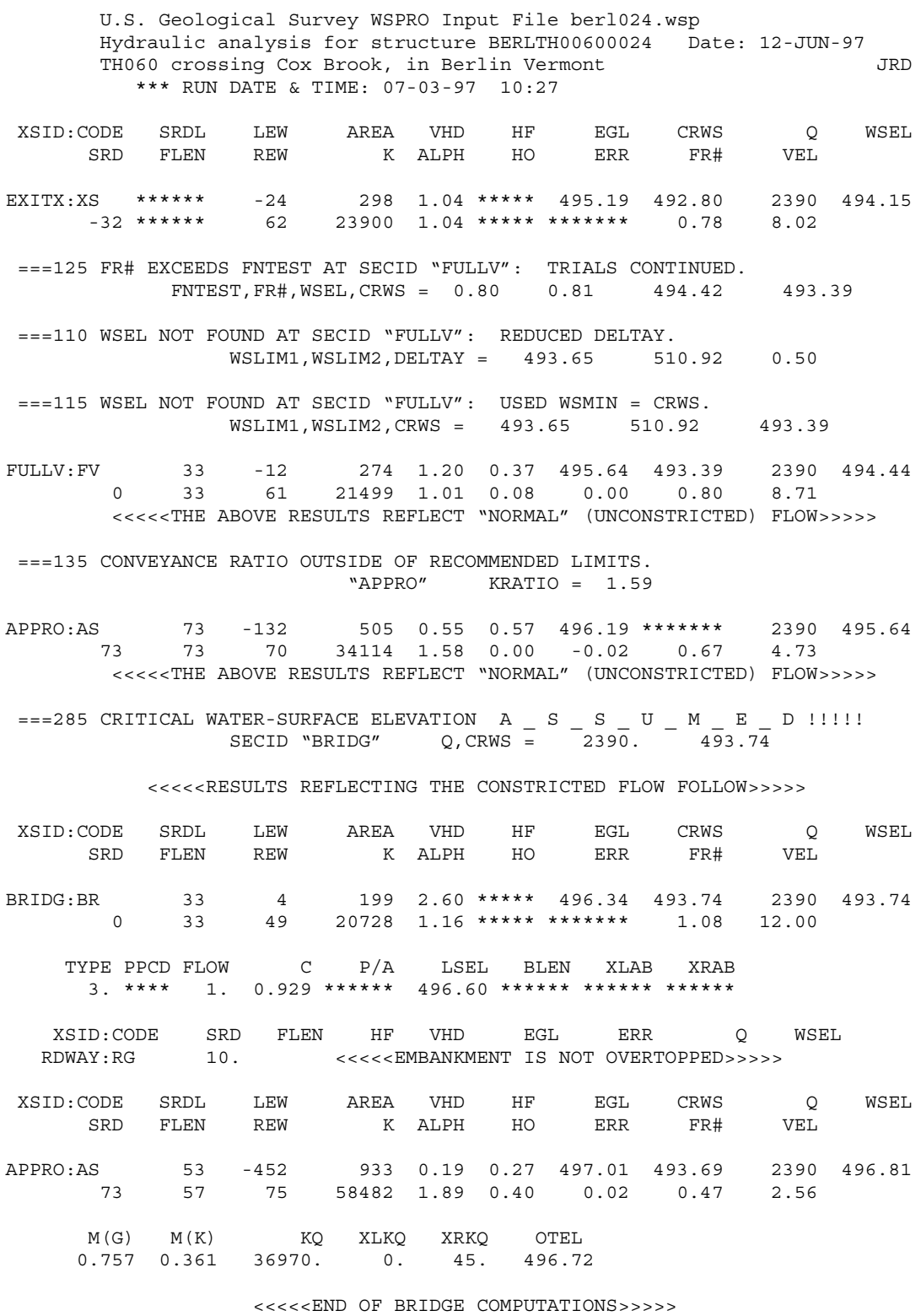

FIRST USER DEFINED TABLE.

\begin{tabular}{|c|c|c|c|c|c|c|c|c|}
\hline XSID : CODE & SRD & LEW & REW & $\mathrm{Q}$ & $\mathrm{K}$ & AREA & VEL & WSEL \\
\hline EXITX:XS & -33 . & -25 . & 62 . & 2390. & 23900 . & 298. & 8.02 & 494.15 \\
\hline FULLV : FV & 0 . & -13 . & 61. & 2390. & 21499 . & 274 & 8.71 & 494.44 \\
\hline BRIDG : BR & 0 . & 4. & 49 . & 2390. & 20728 . & 199. & 12.00 & 493.74 \\
\hline RDWAY : RG & \multicolumn{3}{|c|}{$10 . * \star \star * \star * \star * \star * * * \star * \star * *$} & \multicolumn{3}{|c|}{ 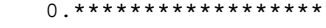 } & \multicolumn{2}{|c|}{$1.00 * * * * * * * *$} \\
\hline APPRO: AS & 73 . & -453. & 75 . & 2390. & 58482 . & 933. & 2.56 & 496.81 \\
\hline XSID : CODE & $\mathrm{XLKQ}$ & XRKQ & & & & & & \\
\hline APPRO : AS & 0 . & 45. & ? & & & & & \\
\hline
\end{tabular}

SECOND USER DEFINED TABLE.

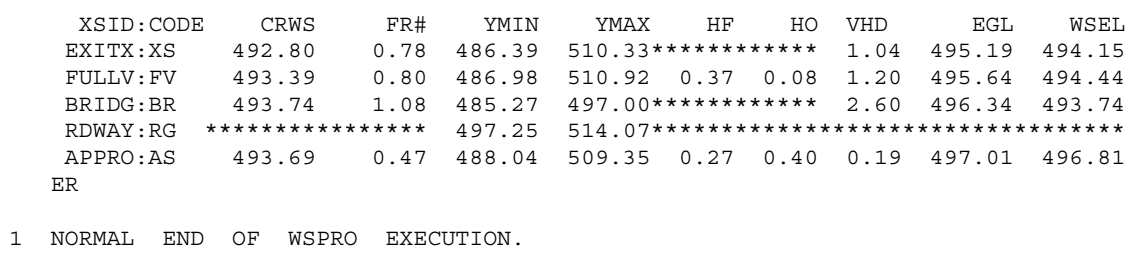




\section{APPENDIX C:}

\section{BED-MATERIAL PARTICLE-SIZE DISTRIBUTION}




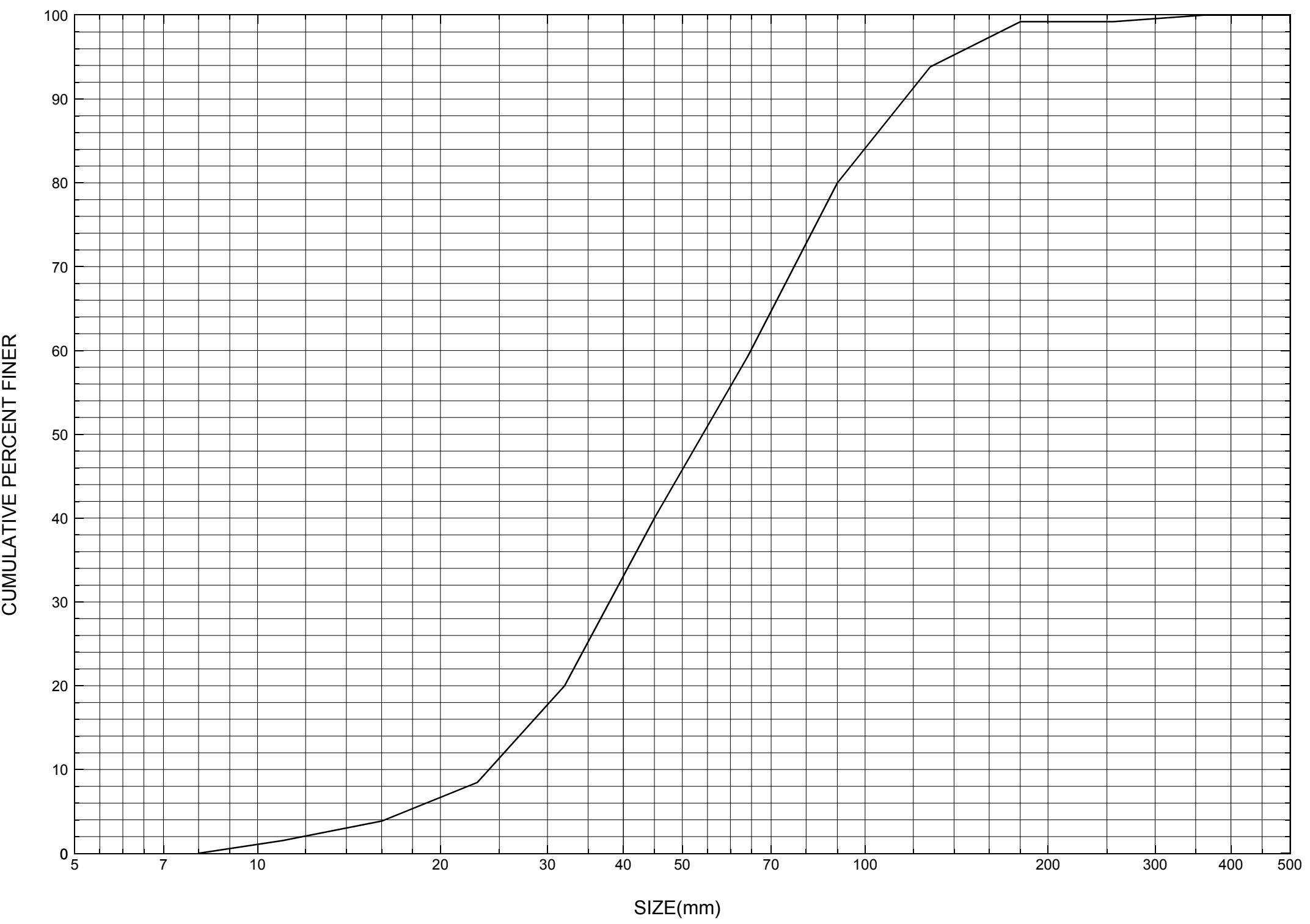

Appendix C. Bed material particle-size distribution for a pebble count in the channel approach of structure BERLTH00600024, in Berlin, Vermont. 


\section{APPENDIX D: \\ HISTORICAL DATA FORM}




\section{Structure Number BERLTH00600024}

\section{General Location Descriptive}

Data collected by (First Initial, Full last name) $\underline{\mathbf{L}}$. Medalie

Date $(M M / D D / Y Y) \_10 / 13 / \underline{95}$

Highway District Number (I - 2; nn) $\mathbf{0 6}$

Town (FIPS place code; I - 4; nnnnn)

Waterway (I - 6) COX BROOK

Route Number C3060

Topographic Map Northfield

Latitude (I - 16; nnnn.n) $\mathbf{4 4 1 1 3}$
County (FIPS county code; I - 3; nnn)

Mile marker (I - 11; nnn.nnn) $\mathbf{0 0 0 0 0 0}$

Road Name (I - 7): -

Vicinity (I - 9) 0.02 MI TO JCT W CL2 TH3

Hydrologic Unit Code: 2010003

Longitude (i - 17; nnnnn.n) $\mathbf{7 2 4 0 5}$

\section{Select Federal Inventory Codes}

FHWA Structure Number (I - 8) $\mathbf{1 0 1 2 0 3 0 0 2 4 1 2 0 3}$

Maintenance responsibility $(I-21 ; n n) \quad \mathbf{0 3} \quad$ Maximum span length $(I-48 ; n n n n) \underline{\mathbf{0 0 5 0}}$

Year built (I - 27; YYYY) 1990

Structure length (I - 49; nnnnnn) $\underline{\mathbf{0 0 0 0 5 9}}$

Average daily traffic, ADT (I - 29; nnnnnn) 000050 Deck Width (I - 52; nn.n) 185

Year of ADT (I - 30; YY) $\mathbf{9 2}$

Channel \& Protection $(I-61 ; n) \underline{\mathbf{8}}$

Opening skew to Roadway $(I-34 ; n n) \quad \mathbf{0 0}$

Waterway adequacy $(I-71 ; n)$

Operational status $(I-41 ; X) \quad \mathbf{A}$

Underwater Inspection Frequency $(I-92 B ; X Y Y) \_\mathbf{N}$

Structure type (I- 43; nnn) $\mathbf{3 0 2}$

Year Reconstructed (I - 106) $\mathbf{0 0 0 0}$

Approach span structure type (I - 44; nnn) $\mathbf{0 0 0}$ Clear span (nnn.n ft) _ _

Number of spans (I - 45; nnn) $\underline{\mathbf{0 0 1}}$

Vertical clearance from streambed (nnn.n ft) -

Number of approach spans (I - 46; nnnn) $\mathbf{0 0 0 0}$

Waterway of full opening $\left(n n n . n \mathrm{ft}^{2}\right)$

Comments:

According to the structural inspection report dated $8 / 15 / 94$, the bridge deck is untreated lumber. There is a gravel buildup around the bearing areas at each abutment. The abutments, wingwalls and backwalls are concrete with minor cracks and small leaks. Stone and boulder riprap has been placed on the embankments in front of the abutments and around their ends. Random boulders and some erosion are showing along the US and DS channel embankments, erosion from past flooding. A couple of trees are in the DS channel. 


\section{Bridge Hydrologic Data}

Is there hydrologic data available? $\underline{\mathbf{N}}$ if No, type ctrl-n $h \quad$ VTAOT Drainage area $\left(m i^{2}\right)$ : -

Terrain character:

Stream character \& type: -

Streambed material:

Discharge Data (cfs):

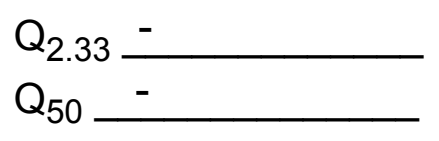

Record flood date $(M M / D D / Y Y):-{ }^{\prime}-$
Estimated Discharge $(c f s):-$

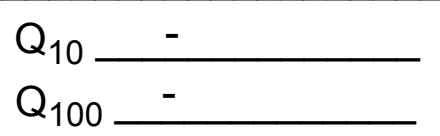

$\mathrm{Q}_{25}$

Water surface elevation $(f t):-$ $(\mathrm{ft} / \mathrm{s}):$

Ice conditions (Heavy, Moderate, Light) : -

Debris (Heavy, Moderate, Light):

The stage increases to maximum highwater elevation (Rapidly, Not rapidly):

The stream response is (Flashy, Not flashy):

Describe any significant site conditions upstream or downstream that may influence the stream's stage: -

Watershed storage area (in percent):

The watershed storage area is: - (1-mainly at the headwaters; 2- uniformly distributed; 3-immediatly upstream oi the site)

Water Surface Elevation Estimates for Existing Structure:

\begin{tabular}{|l|l|l|l|l|l|}
\hline Peak discharge frequency & $Q_{2.33}$ & $Q_{10}$ & $Q_{25}$ & $Q_{50}$ & $Q_{100}$ \\
Water surface elevation (ft)) & - & - & - & - & - \\
Velocity (ft/sec) & - & - & - & - & - \\
\hline
\end{tabular}

Long term stream bed changes: -

Is the roadway overtopped below the $\mathrm{Q}_{100}$ ? (Yes, No, Unknown): $\mathbf{U}$ Frequency: -

Relief Elevation $(f t)$ :

Discharge over roadway at $Q_{100}\left(f t^{3} / \mathrm{sec}\right)$ :

Are there other structures nearby? (Yes, No, Unknown): Upstream distance (miles): Town: If No or Unknown, type ctrl-n os Highway No. :Structure No. : Year Built:

Clear span (ft): Clear Height $(f t)$ : Full Waterway $\left(f^{2}\right)$ : 
Downstream distance (miles): Town: Year Built:

Highway No. : Structure No. : Structure Type:

Clear span (ft): Clear Height $(f t)$ : Full Waterway $\left(f^{2}\right)$ : -

Comments:

\section{USGS Watershed Data}

Watershed Hydrographic Data

Drainage area (DA) $\mathbf{9 . 2 6}$

Watershed storage (ST)

Bridge site elevation $\mathbf{7 8 0}$ $\mathrm{mi}^{2}$ Lake/pond/swamp area 0 $\mathrm{mi}^{2}$

Main channel length $\mathbf{5}$ $10 \%$ channel length elevation $\mathbf{8 1 0}$ $\%$ Headwater elevation 1983 $\mathrm{ft}$ $\mathrm{mi}$

Main channel slope (S)

(S) $146.67 \mathrm{ft} / \mathrm{mi}$

Watershed Precipitation Data

Average site precipitation in Average headwater precipitation in

Maximum 2yr-24hr precipitation event $(124,2)$ in

Average seasonal snowfall (Sn) $\mathrm{ft}$ 


\section{Bridge Plan Data}

Are plans available? $\mathbf{Y}$

If no, type ctrl-n pl Date issued for construction (MM/YYYY):

Project Number R11776

Low superstructure elevation: USLAB $\underline{\mathbf{7 7 3 . 4 2}}$

Minimum channel bed elevation:

Benchmark location description:

DSLAB $\mathbf{7 7 3 . 4 2}$

USRAB 774.24 DSRAB 774.24

$-$

Reference Point (MSL, Arbitrary, Other):

Datum (NAD27, NAD83, Other):

Foundation Type: 1

(1-Spreadfooting; 2-Pile; 3- Gravity; 4-Unknown)

If 1: Footing Thickness $\mathbf{1 . 5} \quad$ Footing bottom elevation: $\mathbf{7 6 7}$

If 2: Pile Type: (1-Wood; 2-Steel or metal; 3-Concrete)

Approximate pile driven length: -

If 3: Footing bottom elevation:

Is boring information available? $\mathbf{N}$ If no, type ctrl-n bi Number of borings taken:

Foundation Material Type: $\mathbf{3}$ (1-regolith, 2-bedrock, 3-unknown)

Briefly describe material at foundation bottom elevation or around piles:

NO DRILL BORING INFORMATION

\section{Comments:}

Bottom of footing at right abutment $=\mathbf{7 6 7 . 2 4}$; at left abutment $=\mathbf{7 6 6 . 4 2}$

The low superstructure elevations are the bridge seat elevations from the bridge plans. 


\section{Cross-sectional Data}

Is cross-sectional data available? $\underline{\mathbf{N}}$ If no, type ctrl-n xs

Source (FEMA, VTAOT, Other)? -

Comments: NO CROSS SECTIONAL INFORMATION

\begin{tabular}{|l|l|l|l|l|l|l|l|l|l|l|l|}
\hline Station & - & - & - & - & - & - & - & - & - & - & - \\
\hline Feature & - & - & - & - & - & - & - & - & - & - & - \\
\hline $\begin{array}{l}\text { Low cord } \\
\text { elevation }\end{array}$ & - & - & - & - & - & - & - & - & - & - & - \\
\hline $\begin{array}{l}\text { Bed } \\
\text { elevation }\end{array}$ & - & - & - & - & - & - & - & - & - & - & - \\
\hline $\begin{array}{l}\text { Low cord to } \\
\text { bed length }\end{array}$ & - & - & - & - & - & - & - & - & - & - & - \\
\hline Station & - & - & - & - & - & - & - & - & - & - & - \\
\hline Feature & - & - & - & - & - & - & - & - & - & - & - \\
\hline $\begin{array}{l}\text { Low cord } \\
\text { elevation }\end{array}$ & - & - & - & - & - & - & - & - & - & - & - \\
\hline $\begin{array}{l}\text { Bed } \\
\text { elevation }\end{array}$ & - & - & - & - & - & - & - & - & - & - & - \\
\hline $\begin{array}{l}\text { Low cord to } \\
\text { bed length }\end{array}$ & - & - & - & - & - & - & - & - & - & - & - \\
\hline
\end{tabular}

Source (FEMA, VTAOT, Other)?

Comments: -

\begin{tabular}{|l|l|l|l|l|l|l|l|l|l|l|l|}
\hline Station & - & - & - & - & - & - & - & - & - & - & - \\
\hline Feature & - & - & - & - & - & - & - & - & - & - & - \\
\hline $\begin{array}{l}\text { Low cord } \\
\text { elevation }\end{array}$ & - & - & - & - & - & - & - & - & - & - & - \\
\hline $\begin{array}{l}\text { Bed } \\
\text { elevation }\end{array}$ & - & - & - & - & - & - & - & - & - & - & - \\
\hline $\begin{array}{l}\text { Low cord to } \\
\text { bed length }\end{array}$ & - & - & - & - & - & - & - & - & - & - & - \\
\hline Station & - & - & - & - & - & - & - & - & - & - & - \\
\hline Feature & - & - & - & - & - & - & - & - & - & - & - \\
\hline $\begin{array}{l}\text { Low cord } \\
\text { elevation }\end{array}$ & - & - & - & - & - & - & - & - & - & - & - \\
\hline $\begin{array}{l}\text { Bed } \\
\text { levation }\end{array}$ & - & - & - & - & - & - & - & - & - & - & - \\
\hline $\begin{array}{l}\text { Low cord to } \\
\text { bed length }\end{array}$ & - & - & - & - & - & - & - & - & - & - & - \\
\hline
\end{tabular}




\section{APPENDIX E: \\ LEVEL I DATA FORM}


U. S. Geological Survey

Bridge Field Data Collection and Processing Form

Qa/Qc Check by: JD Date: $\mathbf{5 / 3 0 / 9 7}$

\section{Structure Number}

BERLTH00600024

Computerized by: JD Date: $\mathbf{5 / 3 0 / 9 7}$

Reviewd by: JD Date: $\underline{8 / 25 / 97}$

\section{A. General Location Descriptive}

1. Data collected by (First Initial, Full last name) $\mathbf{L}$. Medalie

2. Highway District Number 06

Date $(M M / D D / Y Y) \mathbf{0 7} / \mathbf{1 8} / 1996$

County Washington (023)

Mile marker $\mathbf{0}$

Waterway (I - 6) Cox Brook

Route Number TH 6, C3060

Town Berlin (05650)

Road Name -

Hydrologic Unit Code: 2010003

3. Descriptive comments:

This structure is located two hundredths of a mile from the junction with Town Highway 3.

\section{B. Bridge Deck Observations}
4. Surface cover... LBUS 6
RBUS 6
LBDS 4
RBDS 5
Overall 5

(2b us, ds,lb,rb: 1- Urban; 2- Suburban; 3- Row crops; 4- Pasture; 5- Shrub- and brushland; 6- Forest; 7- Wetland)
5. Ambient water surface... US 2
UB 2
DS 2
(1- pool; 2- riffle)

6. Bridge structure type 1 (1- single span; 2- multiple span; 3- single arch; 4- multiple arch; 5-cylindrical culvert; 6- box culvert; or 7- other)
7. Bridge length $\mathbf{5 9 . 0}$
(feet)
Span length $\mathbf{5 0 . 0}$
(feet)
Bridge width 18.5 (feet)

\section{Road approach to bridge:}
8. LB 1
RB 2
( 0 even, 1- lower, 2- higher)
9. LB
RB 1
(1- Paved, 2- Not paved)

10. Embankment slope (run / rise in feet / foot)

$$
\text { US left }
$$

3.3:1

US right

4.3:1

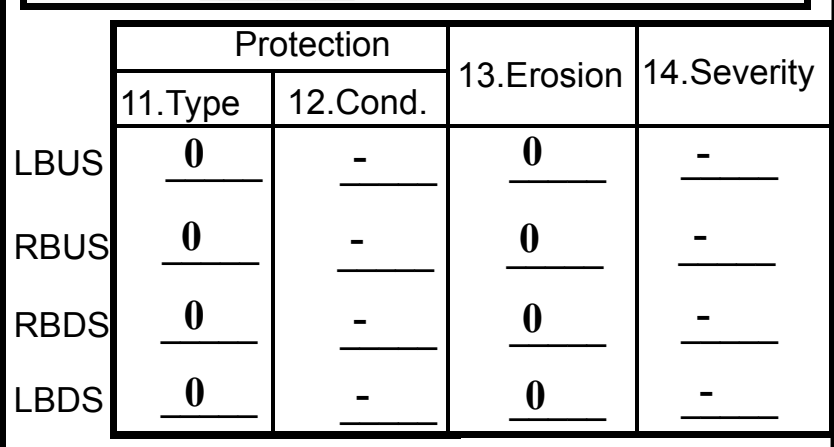

Bank protection types: 0- none; 1- $<12$ inches;

2- < 36 inches; 3- < 48 inches;

4- < 60 inches; 5- wall / artificial levee

Bank protection conditions: 1- good; 2- slumped;

3- eroded; 4- failed

Erosion: 0 - none; 1- channel erosion; 2 -

road wash; 3- both; 4- other

Erosion Severity: 0 - none; 1- slight; 2- moderate; 3- severe

\section{Channel approach to bridge (BF):}

15. Angle of approach: $\mathbf{5}$

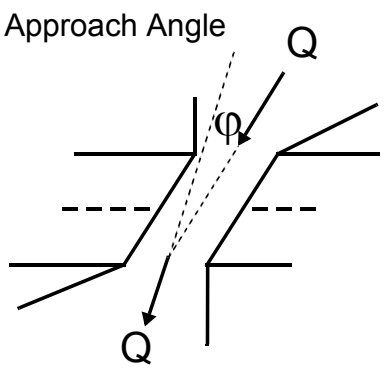

17. Channel impact zone 1 :

Where? RB (LB, RB)

Range? 20 feet US

Channel impact zone 2:

Where? _ _ $(L B, R B)$

Range? - $\quad$ feet -

(US, UB, DS) to Impact Severity: 0- none to very slight; 1- Slight; 2- Moderate; 3- Severe feet -

16. Bridge skew: $\mathbf{5}$ Bridge Skew Angle

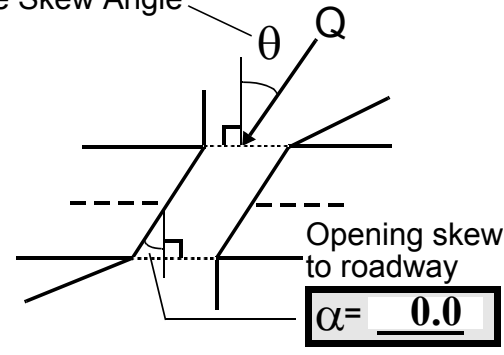

\section{Exist? $\mathbf{Y}(Y$ or $N)$}

Severity 1

(US, UB, DS) to 90 feet $\underline{\mathbf{U S}}$

Exist? $\mathbf{N} \quad($ Yor $N)$

Severity - 
18. Bridge Type: $\mathbf{3}$

1a- Vertical abutments with wingwalls

1 b- Vertical abutments without wingwalls

2- Vertical abutments and wingwalls, sloping embankment Wingwalls perpendicular to abut. face

3- Spill through abutments

4- Sloping embankment, vertical wingwalls and abutments

Wingwall angle less than $90^{\circ}$.

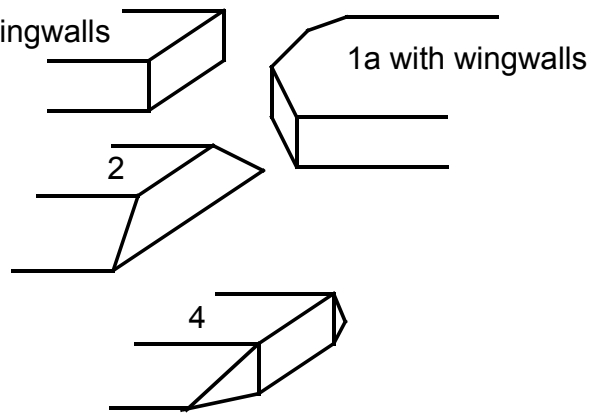

19. Bridge Deck Comments (surface cover variations, measured bridge and span lengths, bridge type variations, approach overflow width, etc.)

7. The measured bridge dimensions at this site differed from those on the historical form. The measured structure length was $57.2 \mathrm{ft}$. The measured span length was $53.5 \mathrm{ft}$.

9. The left road approach is paved for $38 \mathrm{ft}$ beyond the bridge before it switches to gravel.

\section{Upstream Channel Assessment}

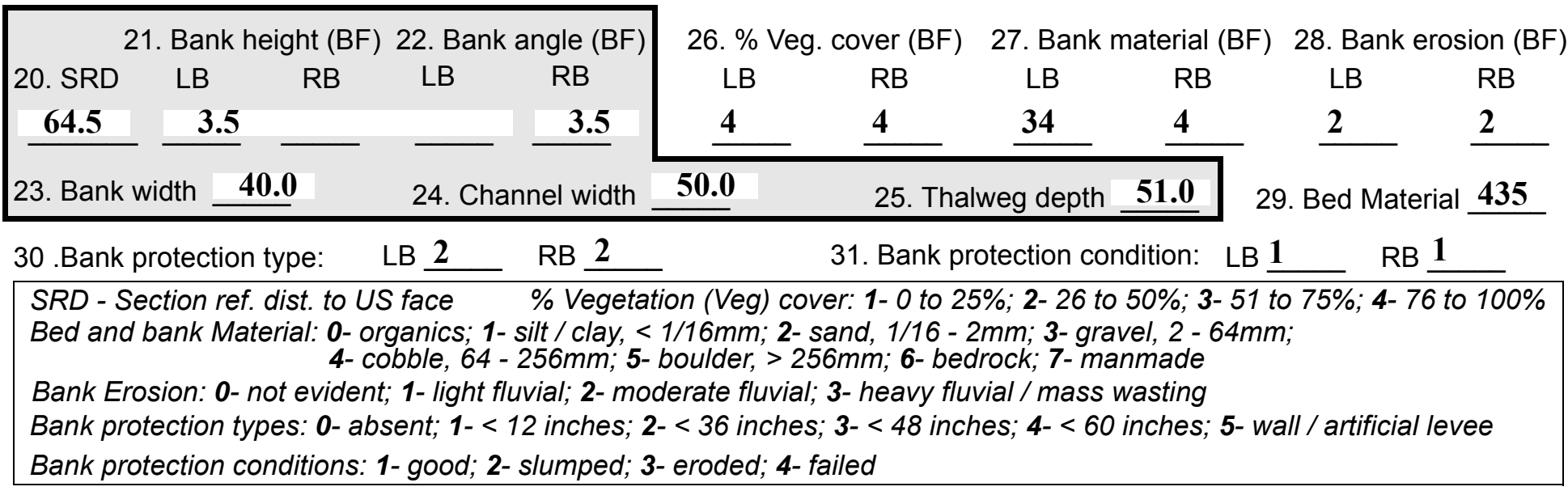

32. Comments (bank material variation, minor inflows, protection extent, etc.):

30. The left bank protection extends from $47 \mathrm{ft}$ upstream to zero $\mathrm{ft}$ upstream. The right bank protection extends from $20 \mathrm{ft}$ upstream to zero ft upstream.

29. Bedrock outcrops in the channel at $100 \mathrm{ft}$ upstream and further upstream intermittently. It appears to have some control of the meanders. 
33.Point/Side bar present? $\mathbf{Y}$

$(Y$ or N. if $N$ type ctrl-n pb)34. Mid-bar distance: 64

35. Mid-bar width: 32

36. Point bar extent: $\underline{\mathbf{1 2}}$ feet $\underline{\mathrm{US}}$ (US, UB) to 110 feet $\underline{\mathbf{U S}}$ (US, UB, DS) positioned $\underline{\mathbf{0}} \%$ LB to $6 \mathbf{5 2} \% \mathrm{RB}$

37. Material: 34

38. Point or side bar comments (Circle Point or Side; Note additional bars, material variation, status, etc.):

This point bar has formed downstream of the bedrock in the channel.

39. Is a cut-bank present? $\mathbf{Y}$ ( $Y$ or if $N$ type ctrl-n cb)

40. Where? $\mathbf{R B}$ (LB or RB)

41. Mid-bank distance: $\mathbf{6 5}$

42. Cut bank extent: 110 feet $\underline{\mathbf{U S}}$ (US, UB) to $\underline{33}$ feet $\underline{\mathbf{U S}}$ (US, UB, DS)

43. Bank damage: 1

(1- eroded and/or creep; 2- slip failure; 3- block failure)

44. Cut bank comments (eg. additional cut banks, protection condition, etc.):

45. Is channel scour present? $\mathbf{N}$ (Yor if $N$ type ctrl-n cs) 46. Mid-scour distance: -

47. Scour dimensions: Length -

Width -

Depth : -

Position -

$\%$ LB to $\% \mathrm{RB}$

48. Scour comments (eg. additional scour areas, local scouring process, etc.):

NO CHANNEL SCOUR

49. Are there major confluences? $\mathbf{N}$

51. Confluence 1: Distance Confluence 2: Distance -

52. Enters on -

Enters on -

54. Confluence comments (eg. confluence name):

NO MAJOR CONFLUENCES
50. How many? -

53. Type(1- perennial; 2- ephemeral)

Type (1-perennial; 2- ephemeral) ( $L B$ or $R B)$

\section{Under Bridge Channel Assessment}

55. Channel restraint (BF)? LB 2

56. Height (BF)
LB RB
$\mathbf{4 4 . 0}-$
58. Bank width (BF) -
59. Channel width $(\mathrm{Amb})$ (1- natural bank; 2- abutment; 3- artificial levee)

Bed and bank Material: 0- organics; 1- silt / clay, < 1/16mm; 2- sand, 1/16 - 2mm; 3- gravel, 2 - 64mm; 4- cobble, 64 - 256mm; 5- boulder, > 256mm; 6- bedrock; 7- manmade

Bank Erosion: 0- not evident; 1- light fluvial; 2- moderate fluvial; 3- heavy fluvial / mass wasting

64. Comments (bank material variation, minor inflows, protection extent, etc.):

435 
65. Debris and Ice Is there debris accumulation?

(Yor $N)$ 66. Where? $\underline{Y}$

(1- Upstream; 2- At bridge; 3- Both)

67. Debris Potential 1 (1-Low; 2-Moderate; 3- High)

68. Capture Efficiency 2

(1-Low; 2- Moderate; 3- High)

69. Is there evidence of ice build-up? 2

Ice Blockage Potential $\underline{\mathbf{Y}}$

(1- Low; 2- Moderate; 3- High)

70. Debris and Ice Comments:

2

Trees are leaning into the channel upstream of the bridge.

\begin{tabular}{|l|c|c|c|c|c|c|c|c|}
\hline Abutments & $\begin{array}{c}\text { 71. Attack } \\
\angle \text { (BF) }\end{array}$ & $\begin{array}{c}72 \text {. Slope } \angle \\
\text { (Qmax) }\end{array}$ & $\begin{array}{c}\text { 73. Toe } \\
\text { loc. (BF) }\end{array}$ & $\begin{array}{c}\text { 74. Scour } \\
\text { Condition }\end{array}$ & $\begin{array}{c}75 . \text { Scour } \\
\text { depth }\end{array}$ & $\begin{array}{c}\text { 76. Exposure } \\
\text { depth }\end{array}$ & 77. Material & 78. Length \\
\hline LABUT & & $\mathbf{0}$ & $\mathbf{6 0}$ & $\mathbf{0}$ & $\mathbf{0}$ & - & - & $\mathbf{9 0 . 0}$ \\
\hline RABUT & $\mathbf{1}$ & $\mathbf{0}$ & $\mathbf{5 5}$ & & & $\mathbf{0}$ & $\mathbf{0}$ & $\mathbf{5 3 . 0}$ \\
\hline
\end{tabular}

Pushed: $L B$ or RB

Toe Location (Loc.): 0- even, 1- set back, 2- protrudes

Scour cond.: 0- not evident; 1- evident (comment); 2- footing exposed; 3-undermined footing; 4- piling exposed; 5- settled; 6- failed

Materials: 1- Concrete; 2- Stone masonry or drywall; 3- steel or metal; 4- wood

79. Abutment comments (eg. undermined penetration, unusual scour processes, debris, etc.):

-

1

72. This measurement is of the stone fill slope in front of each abutment. The abutments have a 90 degree slope.

77. The abutments are concrete.

80. Wingwalls:

Exist? Material? Scour Scour Exposure $\begin{aligned} & 81 . \\ & \text { Angle? Length? }\end{aligned}$ Condition? depth? depth?

USLWW:

53.0

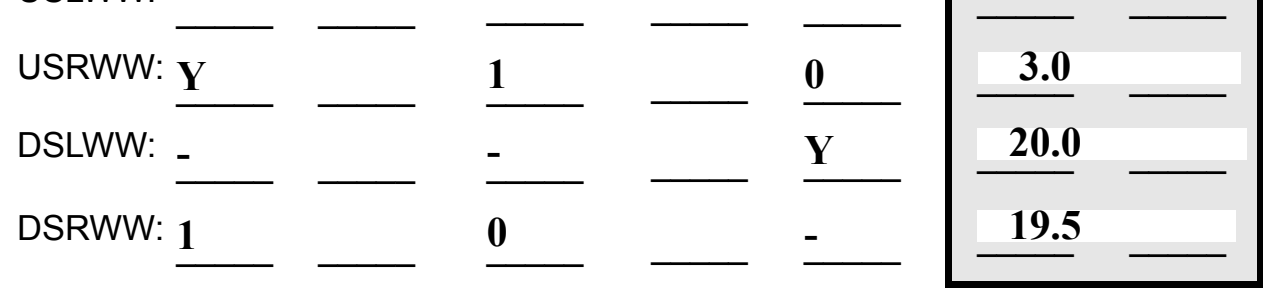

Wingwall materials: 1- Concrete; 2- Stone masonry or drywall; 3- steel or metal; 4- wood

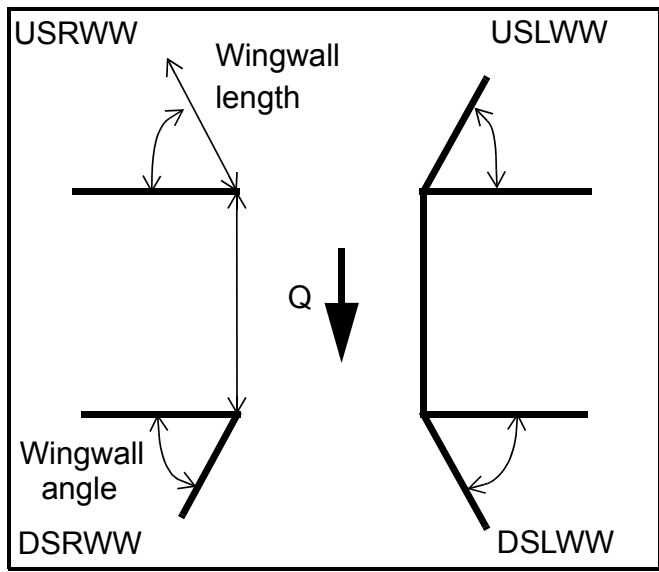

82. Bank / Bridge Protection:

\begin{tabular}{|l|l|l|l|l|l|l|l|c|}
\hline Location & USLWW & USRWW & LABUT & RABUT & LB & RB & DSLWW & DSRWW \\
\hline Type & - & $\mathbf{0}$ & $\mathbf{Y}$ & - & $\mathbf{1}$ & $\mathbf{1}$ & $\mathbf{1}$ & $\mathbf{1}$ \\
\hline Condition & $\mathbf{Y}$ & - & $\mathbf{1}$ & - & $\mathbf{1}$ & $\mathbf{1}$ & $\mathbf{1}$ & $\mathbf{1}$ \\
\hline Extent & $\mathbf{1}$ & - & $\mathbf{0}$ & $\mathbf{2}$ & $\mathbf{2}$ & $\mathbf{2}$ & $\mathbf{2}$ & - \\
\hline
\end{tabular}

Bank / Bridge protection types: 0- absent; 1- < 12 inches; 2- < 36 inches; 3- < 48 inches; 4- < 60 inches; 
83. Wingwall and protection comments (eg. undermined penetration, unusual scour processes, etc.):

-
-
-
-
-
2
1
1
2
1
1

\section{Piers:}

84. Are there piers? Th (Y or if $N$ type ctrl-n pr)

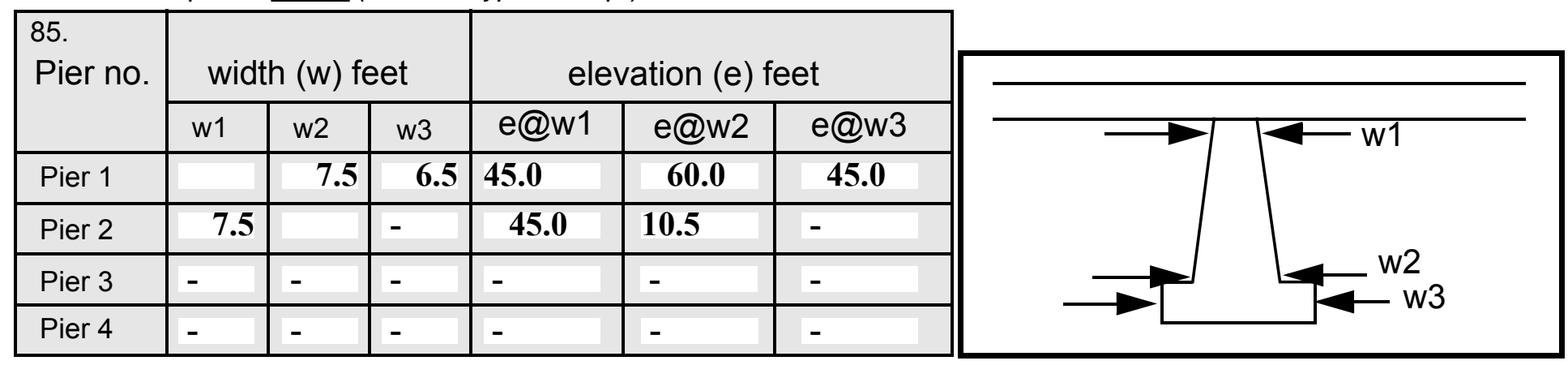

\begin{tabular}{|c|c|c|c|c|}
\hline Level 1 Pier Descr. & 1 & 2 & 3 & 4 \\
\hline 86. Location (BF) & e stone & • & - & - \\
\hline 87. Type & fill & & - & - \\
\hline 88. Material & spill- & & - & - \\
\hline 89. Shape & thro & & - & - \\
\hline 90. Inclined? & ugh & & - & - \\
\hline 91. Attack $\angle(B F)$ & slope & & - & - \\
\hline 92. Pushed & exte & & - & - \\
\hline 93. Length (feet) & - & - & - & - \\
\hline 94. \# of piles & nds & & - & - \\
\hline 95. Cross-members & alon & & - & - \\
\hline 96. Scour Condition & g the & & - & - \\
\hline 97. Scour depth & wing & & - & - \\
\hline 98. Exposure depth & walls & $\mathbf{N}$ & - & - \\
\hline
\end{tabular}

LFP, LTB, LB, MCL, MCM, MCR, RB, RTB, RFP

1- Solid pier, 2- column, 3- bent

1-Wood; 2- concrete; 3- metal; 4- stone

1- Round; 2- Square; 3- Pointed

Y-yes; $N-$ no

$L B$ or $R B$

0- none; 1- laterals; 2- diagonals; 3- both

0- not evident; 1- evident (comment);

2- footing exposed; 3- piling exposed;

4- undermined footing; 5- settled; 6-failed 
99. Pier comments (eg. undermined penetration, protection and protection extent, unusual scour processes, etc.):

-
-
-
-
-
-
-
-
-
-

100.

\section{E. Downstream Channel Assessment}

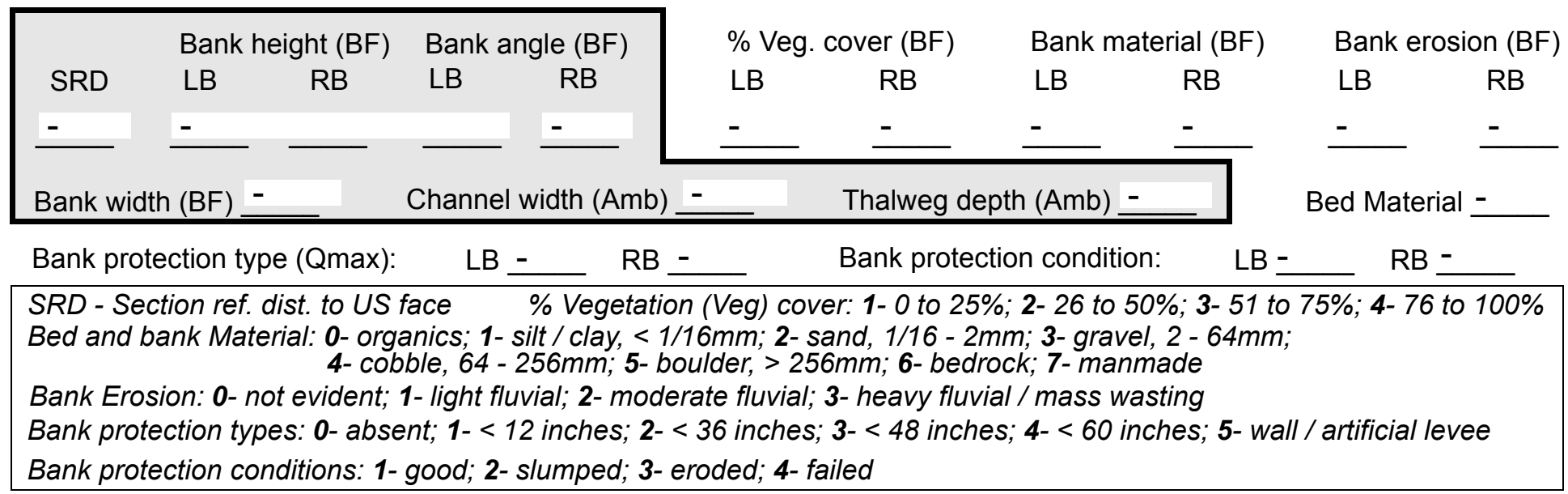

Comments (eg. bank material variation, minor inflows, protection extent, etc.):

$$
-
$$

$-$

$-$

\section{NO PIERS}

101. Is a drop structure present? 43 ( $Y$ or $N$, if $N$ type ctrl-n ds) 102. Distance: - feet 103. Drop: ___ feet 104. Structure material: $\mathbf{2 3}$ (1- steel sheet pile; 2-wood pile; 3- concrete; 4- other) 105. Drop structure comments (eg. downstream scour depth): 0

1

435

1 
Point bar extent: vege- feet tati (US, UB, DS) to on feet $\underline{\text { cov }}$ (US, UB, DS) positioned er \%LB to is $\%$ RB Material: less

Point or side bar comments (Circle Point or Side; note additional bars, material variation, status, etc.):

than $50 \%$ upstream of $85 \mathrm{ft}$.

The bank protection extends to $26 \mathrm{ft}$ on both banks.

The protection is mostly type 1 , with some type 2 stone fill towards the bottom of the bank.

The bed material gets finer towards right bank.

Is a cut-bank present? Th (Y or if $N$ type ctrl-n $c b)$ Where? e (LB or RB) Mid-bank distance: left

Cut bank extent: bank feet ero (US, UB, DS) to sion feet inc (US, UB, DS)

Bank damage: rea (1- eroded and/or creep; 2- slip failure; 3- block failure)

Cut bank comments (eg. additional cut banks, protection condition, etc.):

ses beyond $80 \mathrm{ft}$ downstream to light fluvial.

Is channel scour present? ( $Y$ or if $N$ type ctrl-n cs)

Mid-scour distance:

Scour dimensions: Length Width Depth:

Positioned $\%$ LB to $\% \mathrm{RB}$

Scour comments (eg. additional scour areas, local scouring process, etc.):

N

$-$

NO DROP STRUCTURE

Are there major confluences? ( $Y$ or if $N$ type ctrl-n $m c)$

How many?

Confluence 1: Distance Enters on ( $L B$ or $R B)$

Confluence 2: Distance 95

Enters on 11 (LB or $R B)$

Type $\underline{\mathbf{Y}}$

(1-perennial; 2- ephemeral)

Confluence comments (eg. confluence name):

DS

105

\section{F. Geomorphic Channel Assessment}

$\begin{array}{ll}\text { 107. Stage of reach evolution DS } & \text { 1- Constructed } \\ & \mathbf{2} \text { - Stable } \\ \mathbf{3} \text { - Aggraded } \\ \mathbf{4} \text { - Degraded } \\ \mathbf{5} \text { - Laterally unstable } \\ \mathbf{6} \text { - Vertically and laterally unstable }\end{array}$


108. Evolution comments (Channel evolution not considering bridge effects; See HEC-20, Figure 1 for geomorphic descriptors):

5

40

34

This side bar is covered with grass. There is an additional side bar beginning at $120 \mathrm{ft}$ downstream, that consists of gravel and cobbles.

$\mathbf{N}$

$-$

$-$ 


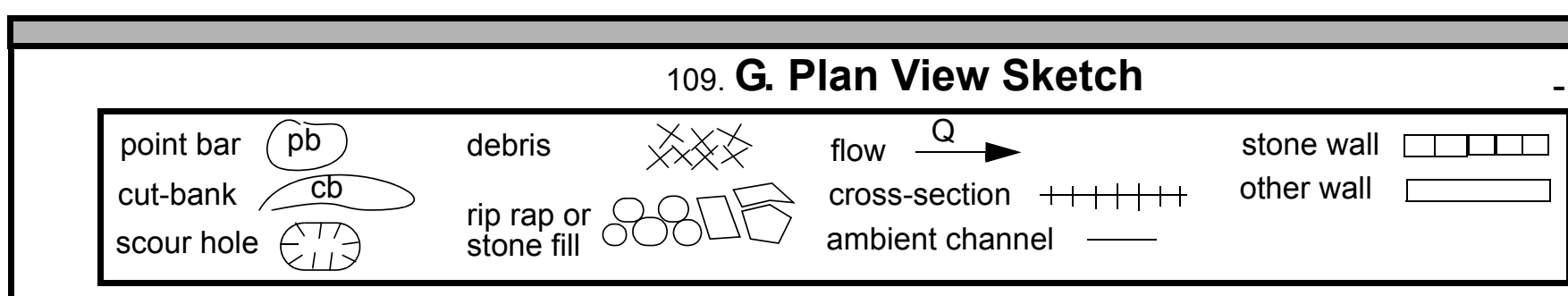


APPENDIX F:

SCOUR COMPUTATIONS 


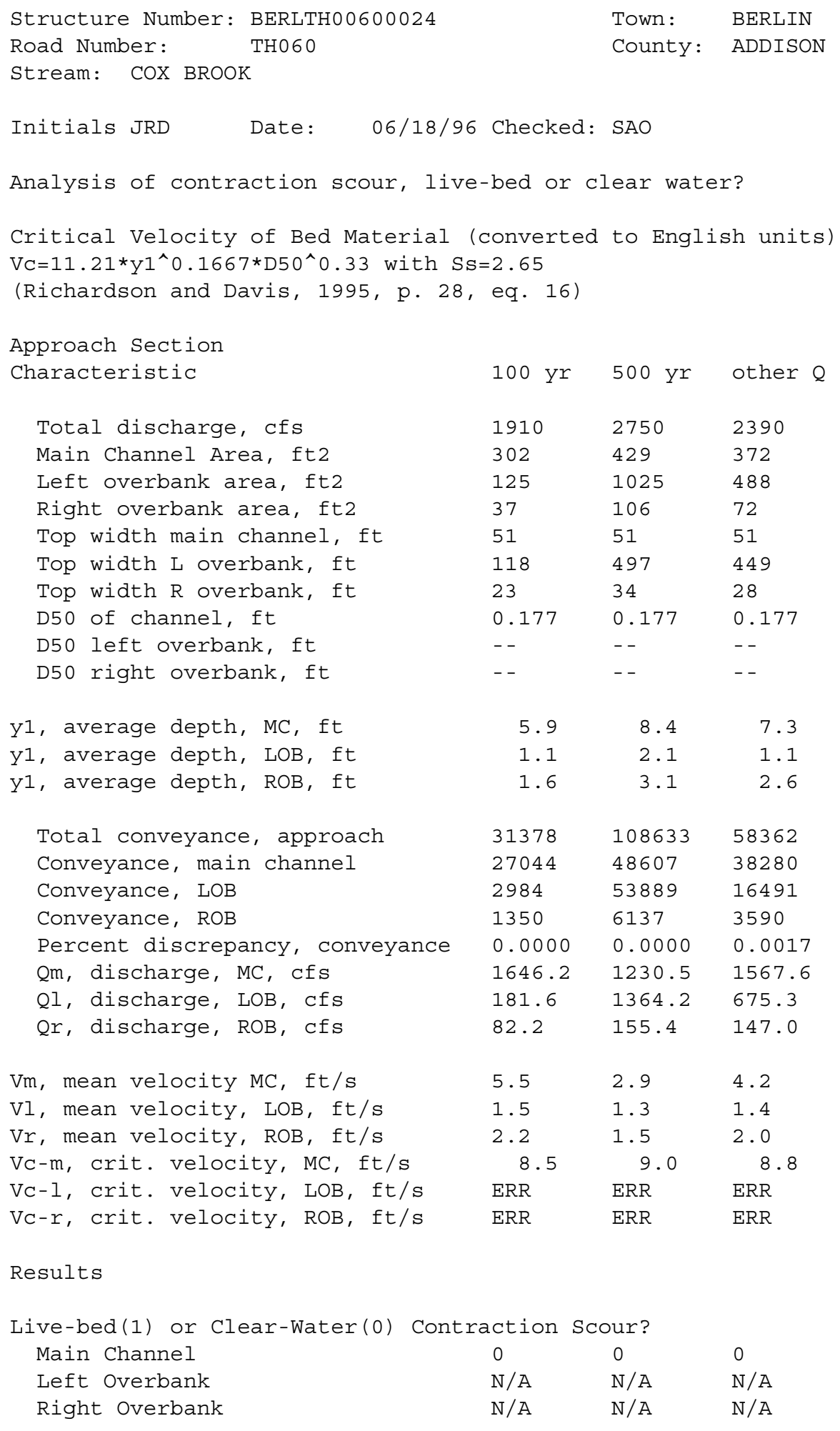


Clear water Contraction Scour in MAIN CHANNEL

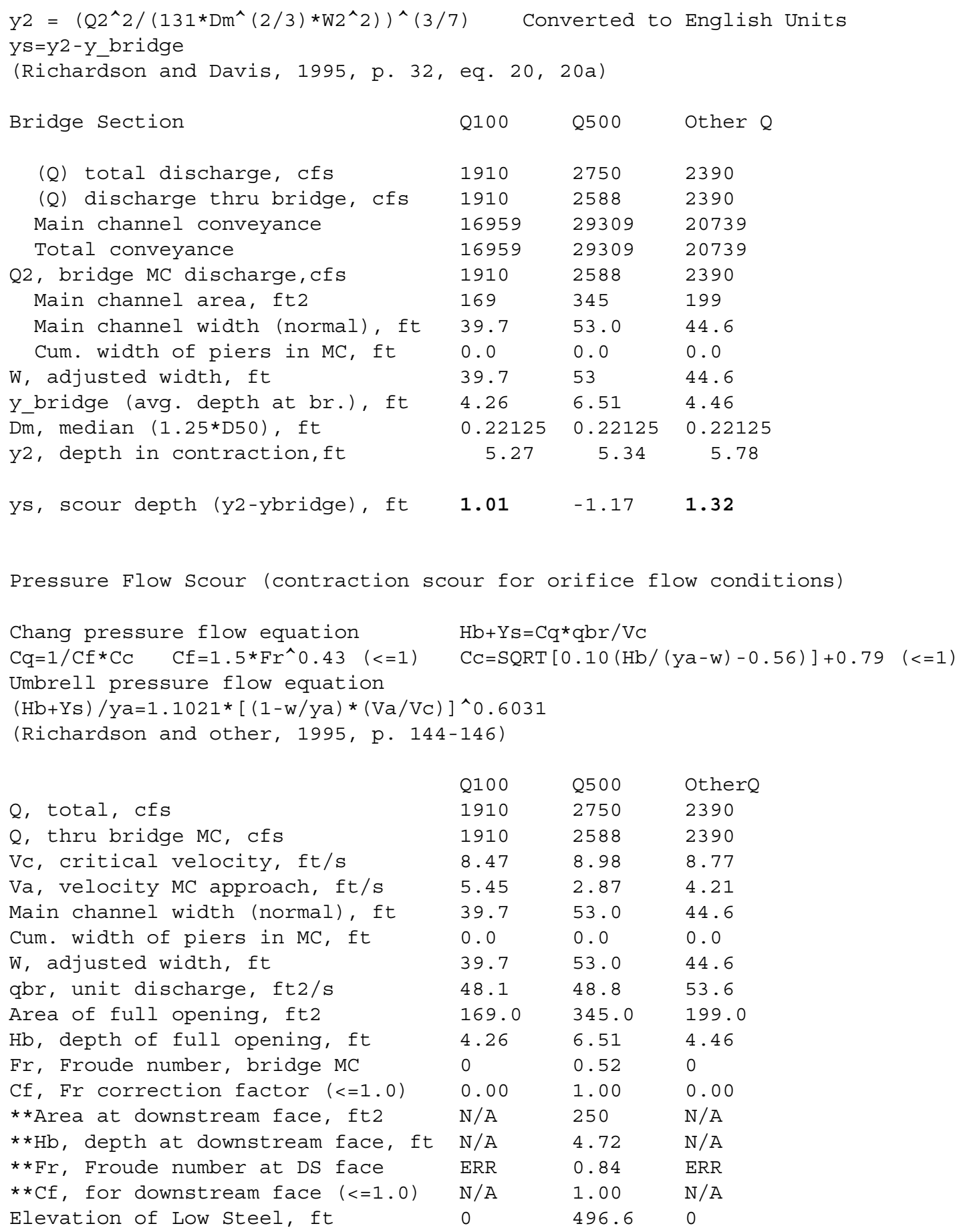


Elevation of Bed, ft

Elevation of Approach, ft

Friction loss, approach, ft

Elevation of WS immediately US, ft

ya, depth immediately US, ft

Mean elevation of deck, ft

$\mathrm{w}$, depth of overflow, ft $(>=0)$

$\mathrm{CC}_{\mathrm{C}}$, vert contrac correction $(<=1,0) 1.00$

$* * \mathrm{CC}$, for downstream face $(<=1.0)$ ERR

Ys, scour w/Chang equation, ft

Ys, scour w/Umbrell equation, ft
$-4.26$

$0 \quad 0.14 \quad 0$

$0.00 \quad 497.80 \quad 0.00$

$\begin{array}{lll}4.26 & 7.71 & 4.46\end{array}$

$\begin{array}{lll}0 & 499.6 & 0 \\ 0.00 & 0.00 & 0.00\end{array}$

$\begin{array}{lll}.00 & 0.96 \quad 1.00\end{array}$

ERR $\quad 0.862004$ ERR

N/A $\quad-0.83 \quad N / A$

N/A $\quad-2.24 \quad N / A$

**=for UNsubmerged orifice flow using estimated downstream bridge face properties.

**Ys, scour w/Chang equation, ft N/A $1.59 \quad \mathrm{~N} / \mathrm{A}$

**Ys, scour w/Umbrell equation, ft ERR -0.45 ERR

In UNsubmerged orifice flow, an adjusted scour depth using the Laursen equation results and the estimated downstream bridge face properties can also be computed (ys=y2-ybridgeDs)

y2, from Laursen's equation, ft $5.27 \quad 5.34 \quad 5.78$

WSEL at downstream face, ft -- 494.79 --

Depth at downstream face, ft N/A 4.72 N/A

Ys, depth of scour (Laursen), ft N/A 0.62 N/A

\section{Armoring}

$\mathrm{DC}=\left[\left(1.94 * \mathrm{~V}^{\wedge} 2\right) /(5.75 * \log (12.27 * \mathrm{y} / \mathrm{D} 90))^{\wedge} 2\right] /[0.03 *(165-62.4)]$

Depth to Armoring $=3 *(1 / \mathrm{PC}-1)$

(Federal Highway Administration, 1993)

$\begin{array}{llll}\text { Downstream bridge face property } & 100-\mathrm{yr} & 500-\mathrm{yr} & \text { Other Q } \\ \text { Q, discharge thru bridge MC, Cfs } & 1910 & 2588 & 2390 \\ \text { Main channel area (DS), ft2 } & 169 & 250 & 199 \\ \text { Main channel width (normal), ft } & 39.7 & 53 & 44.6 \\ \text { Cum. width of piers, ft } & 0.0 & 0.0 & 0.0 \\ \text { Adj. main channel width, ft } & 39.7 & 53.0 & 44.6 \\ \text { D90, ft } & 0.3810 & 0.3810 & 0.3808 \\ \text { D95, ft } & 0.4520 & 0.4520 & 0.4518 \\ \text { Dc, critical grain size, ft } & 0.5332 & 0.4292 & 0.5906 \\ \text { PC, Decimal percent coarser than } & \text { DC N/A } & 0.056 & \text { N/A } \\ \text { Depth to armoring, ft } & & & \\ \end{array}$

Abutment scour

Froehlich's Abutment Scour

$\mathrm{Ys} / \mathrm{Y} 1=2.27 * \mathrm{~K} 1 * \mathrm{~K} 2 *\left(\mathrm{a}^{\prime} / \mathrm{Y} 1\right)^{\wedge} 0.43 * \mathrm{Fr} 1^{\wedge} 0.61+1$

(Richardson and Davis, 1995, p. 48, eq. 28)

\begin{tabular}{|c|c|c|c|c|c|c|c|}
\hline \multirow[b]{2}{*}{ Characteristic } & \multicolumn{3}{|c|}{ Left Abutment } & \multicolumn{4}{|c|}{ Right Abutment } \\
\hline & & $100 \mathrm{yr}$ & $00 \mathrm{y} r$ & ther $\mathrm{Q}$ & $00 \mathrm{yr}$ & $0 \mathrm{yr}$ & her Q \\
\hline (Qt), total discharge, & $\operatorname{cfs}$ & 1910 & 2750 & 2390 & 1910 & 2750 & 2390 \\
\hline$a^{\prime}$, abut.length blocking & flow, ft & 129.3 & 501.2 & 456.9 & 22.7 & 27.3 & 26.2 \\
\hline
\end{tabular}




\begin{tabular}{|c|c|c|c|c|c|c|}
\hline Ae, area of blocked flow ft2 & 175.9 & 993.2 & 533.5 & 38.9 & 83.54 & 66.8 \\
\hline Qe, discharge blocked abut., cfs & 405.9 & -- & 829 & 90 & 118.79 & 138.6 \\
\hline (If using Qtotal_overbank to obta & in $\mathrm{Ve}$, & ave Qe & ank anc & nter $v$ & id Fr m & גally) \\
\hline $\mathrm{Ve},(\mathrm{Qe} / \mathrm{Ae}), \mathrm{ft} / \mathrm{s}$ & 2.31 & 1.35 & 1.55 & 2.31 & 1.42 & 2.07 \\
\hline ya, depth of $f / p$ flow, ft & 1.36 & 1.98 & 1.17 & 1.71 & 3.06 & 2.55 \\
\hline --Coeff., K1, for abut. type (1.0, & verti.; & $.82, \mathrm{ve}$ & i. w/ & Igwall; & 55, spi & thru) \\
\hline $\mathrm{K} 1$ & 0.55 & 0.55 & 0.55 & 0.55 & 0.55 & 0.55 \\
\hline --Angle (theta) of embankment $(<90$ & if abut & points & $i>90$ & abut. & nts US) & \\
\hline theta & 90 & 90 & 90 & 90 & 90 & 90 \\
\hline K2 & 1.00 & 1.00 & 1.00 & 1.00 & 1.00 & 1.00 \\
\hline Fr, froude number $\mathrm{f} / \mathrm{p}$ flow & 0.349 & 0.164 & 0.253 & 0.311 & 0.143 & 0.229 \\
\hline ys, scour depth, ft & 7.69 & 10.85 & 9.39 & 4.90 & 6.05 & 6.08 \\
\hline
\end{tabular}

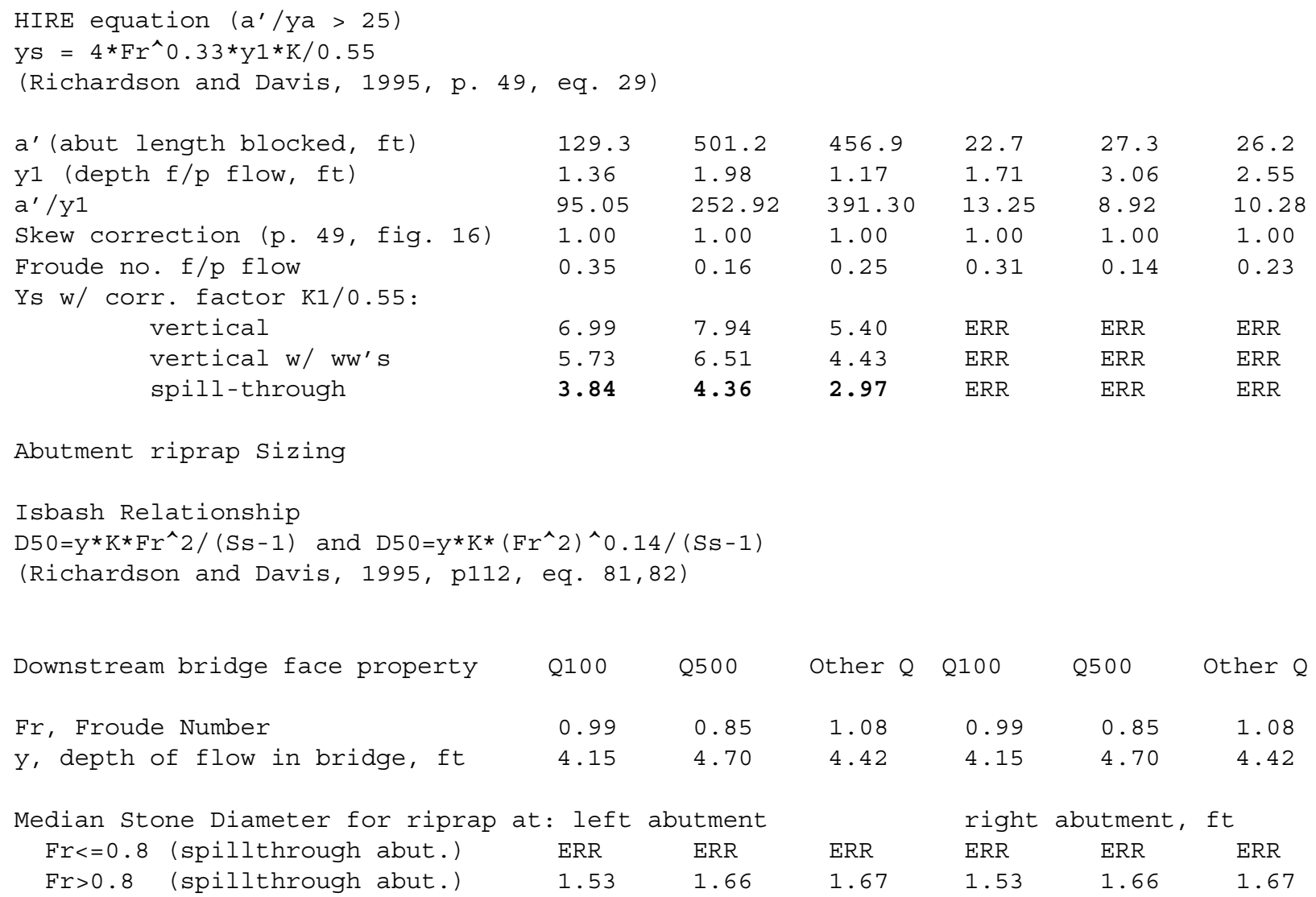


